ANU 13 June 2016

\title{
Employment effects of trade reform in the Vietnamese banking industry
}

\author{
Huong Dinh \\ Huong.Dinh@anu.edu.au \\ Research Fellow \\ Research School of Economics \\ Australian National University
}

\begin{abstract}
In response to the call for evidence of sectoral employment impacts of services trade reform, the paper examines how trade liberalisation in the Vietnam's banking industry would change employment between sectors and total employment under in two macroeconomic settings: fixed versus variable labour supply. Using the FTAP-VN model and GTAP 7 Database, the paper finds that potential trade reform in Vietnam's banking industry could have significant impacts on employment across industries in the economy regardless of the labour supply assumptions. Apart from the employment relocation effect as in the fixed labour supply, trade reform with a variable labour supply would expand jobs in all industries, increasing total employment by $6.3 \%$. Trade reform would most benefit employment in the financial services itself and the industries with close linkages with the financial sector and facing the highest reduction in the relative price of labour to capital. In any cases, services would gain the most in terms of job creation from the trade reform. Services would also absorb most of the increased labour supply, followed by manufacturing and agriculture and mining. With a fixed labour supply, trade reform would encourage a substitution of unskilled labour for skilled labour across industries, placing skilled labour in a relatively disadvantaged position in the short run. In the short and median run, in order to avoid a shortage of skilled labour and consequent pressure on wages, Vietnam would need to invest in education and training to create a better skilled labour force, particularly in banking and finance. With a variable labour supply, in the long-run, the pressure on wage increase and substitution of skilled labour for unskilled labour could be mitigated with the transformation of unskilled labour into skilled labour and the increasing labour supply.
\end{abstract}


The banking industry has been the most important channel of credit for investment and economic growth in Vietnam - one of the emergent developing countries in South East Asian with an average growth of 7.5\% per annum during the period 1995-2014 (World Bank, 2014b). Of the finance system, it accounts for $92 \%$ of total assets (World Bank, 2014a), provides $80 \%$ of national capital flows to all economic sectors (Hoang, 2004). The banking industry is large in terms of both deposits and credits measurement. Over the last two decades, driven by a large savings ratio and rapid economic growth, the ratio of bank deposits to GDP increased sharply from 23\% in 1992 (Dinh, 2011) to 110\% in 2011, well exceeding the international benchmarks (World Bank, 2014a). The ratio of credit to GDP also expanded significantly in the same period, especially during 2007-2010 when the ratio was $108 \%$ on average, also well-beyond the relevant benchmark (World Bank, 2014a).

During the last two decades of economic renovation 'Doi Moi', the Vietnamese banking industry has made significant trade reforms toward a market-oriented banking system via both domestic reform and international trade integration including the World Trade Organisation General Agreement on Trade and Services (WTO GATS) commitments (de Waal et al., 2009; Dinh, 2011). The sector has moved from a mono- into a two-tier system which includes the State Bank of Vietnam in the first tier and mixed players (in 2014, five state-owned commercial banks (SOCBs), 33 joint-stock commercial banks (JSCBs), five joint-venture banks, five wholly foreign-owned banks) in the second tier. The banking market has been gradually opened to both domestic private and foreign investment. Bank restructuring has been carried out intermittently in attempt to improve the efficiency of the banking industry: capital injections, non-performing loans disposal and equitisation on state-owned commercial banks (SOCBs) while a round of consolidating, merge and acquisition on joint-stock commercial banks (Vo et al., 2004).

Despite positive reforms, there are still more to be done. First, equitisation of the four SOCBs which accounts for $60 \%$ of the market needs to be pushed quicker so that their operational efficiency could be improved. The dominance of state ownership in the banking system retards market competition, raises discrimination against the private sector in accessing credits from SOCBs, generates more interconnectedness between SOCBs and state-owned enterprises, thereby jeopardising the efficiency of credit allocation. Second, the interest rate ceilings should be abolished to mitigate unnecessary transaction costs due to non-transparent competition between banks in fund mobilisation and lending activities. For example, banks circumvented the cap on interest rates by charging up-front fees to borrowers and giving bonuses to depositors. Third, administrative measures applied to deposit-taking and lending activities, foreign exchange business and network expansion need to be replaced by market measures. Specifically, in the foreign exchange business, both price (exchange rate) and quantity (volume of transactions) are strictly controlled. The spot exchange rate between the United States dollar and the Vietnamese dong quoted by authorized credit institutions must be in the band of $\pm 3 \%$ of the inter-bank exchange rate notified by the State Bank of Vietnam (SBV). During shortages of foreign currency, exporters are forced to sell their foreign currency revenue to SBV. While it seems plausible for the central bank to intervene in the foreign exchange market in order to keep the currency stable, such measures create a significant gap between the official and market exchange rates. Given such a gap, banks hesitate to sell foreign exchange to firms, which often have to rely on the black market to buy dollars for their imports. Finally, current restrictions on foreign banks' establishment and operation, including restrictions on presence of natural persons, can be further liberalised so as to create more competition and thus improve the efficiency of the banking system.

To our awareness, Dinh's (2012) study was the first research that looks at the economy-wide employment effects of trade liberalisation in the Vietnamese banking industry. The author uses a multiple-regional, multi-sectoral computable general equilibrium model which incorporates foreign direct investment (FDI) - the so called FTAP model using the Global Trade Analysis Project (GTAP) Data Base 7 of the country-specific input-output tables for 113 regions and 57 sectors. In her model, Dinh assumes a fixed total employment and finds that trade liberation in the banking industry is projected to increase in the unskilled employment in seven out of 32 aggregated sectors: (i) coal, oil and gas mining; (ii) electricity and gas production and distribution; (iii) water; (iv) construction; (v) trade; (vi) financial services excluding insurance; and (vii) recreational and other services. The reform would also cause a minor job contraction in the other sectors. For skilled workers, trade reforms would 
improve employment only in the financial services sector (excluding insurance) while would slash jobs in the other sectors.

Although Dinh's (2011) study provides useful insights into how employment would change between sectors due to trade reform, her projected results are likely to be overestimated or underestimated under the fixed total employment assumption. If a sector experienced an output expansion, its demand for labour would increase. This increased demand for labour must be met only by moving labour from other sectors in case of the fixed total employment while could also be addressed by a higher labour supply under the variable total employment assumption. In Vietnam, a significant proportion of labour is in the informal market (Hanoi National Economics University, 2011) and is not captured in the GTAP7 Database; there is a constant trend of moving labour from the informal to formal market, so the fixed total employment assumption turns out to be unrealistic. In addition, with a young and increasing population, the labour supply is likely to increase overtime. As such, we would expect less job contractions in case of the variable total employment.

This paper aims to address this gap and therefore enrichs evidence of employment effects of service trade reform. We examine how trade liberalisation in the Vietnam's banking industry would change employment between sectors and total employment under in two macroeconomic settings: fixed versus variable total employment. In particular, the paper seeks to answer the following research questions:

- Under trade reform in the banking industry, which sectors would be expanding in jobs and how could banking services trade reform contribute to their employment expansion? Are the expanding sectors the same between the two macroeconomic settings?

- Under trade reform in the banking industry, which sectors would be contracting in jobs and how could banking services trade reform lead to their employment contraction? Are the contracting sectors the same between the two macroeconomic settings?

- Under trade reform in the banking industry, what type of labour would see an improvement/deterioration in wages?

- Overall, would trade reform in the banking industry lead to an increase in total employment if total employment is allowed to be variable?

To address these research questions, this study first reviews the current regulatory barriers to trade in banking services in Vietnam (Section 2). This is an essential part as it provides inputs for our simulations latter. We next show the first-round impacts of trade barriers in banking services on bank performance (Section 3). We then simulate the economy-wide effects of removing barriers to trade in banking services in Section 4 using the inputs in the previous sections. This section details methodology, data and results of the simulations. Section 5 concludes.

\section{Restrictions in the Vietnamese banking industry}

Although there is enormous potential for Viet Nam to further develop its banking industry, ${ }^{1}$ the expansion of the industry remains limited (Dinh, 2012; Dinh, 2011; IFC, 2009). The main barriers to the development of the country's banking industry are: (i) regulations discriminating against foreign entry or limiting the nature and scope of foreign operations; and (ii) regulations limiting new entry or restricting the nature and scope of operations of newcomers once they have entered, regardless of whether they are domestically or foreign owned. Based on the framework for assessing barriers to trade in banking services developed by McGuire and Schuele (2000), Dihel and Shepherd (2007) and World Bank (undated), Dinh (2011) develops a questionnaire that evaluates non-prudential regulation restricting banking services delivered through all four modes of supply (cross-border - mode 1; the movement of consumers -mode 2; commercial presence - mode 3; the movement of individual bank

\footnotetext{
${ }^{1}$ For example, up to $50 \%$ of Vietnamese enterprises did not have access to credit from the formal financial sector. In particular, only $22 \%$ used bank loans for investment. Among those that took out loans, bank loans accounted for only $12.7 \%$ of their total investments (IFC 2009).
} 
personnel, particularly intra-corporate transferees - mode 4) in 36 countries over the period 1996-2006. While covering restrictions by modes of supply, as in Diehl and Shepherd (2007), Dinh's template also differentiates restrictions on domestic banks from those on foreign banks. This treatment helps to identify pure discrimination against foreigners (11 restrictions) apart from those commonly affecting both domestic and foreign banks (13 restrictions). Each restriction category is given a score between 0 and 1 ( 0 - the least restrictive; 1 - the most restrictive) using the information from the WTO GATS schedules, the WTO Trade Policy Reviews, the APEC Individual Action Plans, the National Trade Estimates Reports on Foreign Trade Barriers from the Office of the United States Trade Representative, various editions of the International Financial Law Review, country-specific legal documents and other publications. The scores are then aggregated to produce the summary trade restrictiveness indices using the weights produced by the principal component analysis. This section discusses about the degree of restrictiveness in banking services in Vietnam compared with other countries using Dinh's (2011) study.

Figures 1 and 2 show the variation in restrictions affecting banking services of domestic and foreign banks across countries and different country groups over the decade 1997-2006. The difference between TRI_FA and TRI_D indicates the overall discrimination against locally-incorporated foreign banks, taking into account both the differential application of the common restrictions, and the additional restrictions that apply only to foreign banks. A comparison of TRI_D and TRI_FB shows whether the common restrictions are applied differently to domestic and locally-incorporated foreign banks. The difference between TRI_F and TRI_D shows the overall discrimination against foreign banks, taking into account the restrictions on cross-border trade and consumption abroad.

In the 36 countries studied, Vietnam and other Asian countries dominated the top-ten countries with the highest degree of restrictiveness on both domestic banks and locally-incorporated foreign banks. OECD countries in the EU had the lowest restrictiveness compared to other groups. Most of the EU countries had a low degree of restrictiveness, even smaller than the lowest countries in other groups. In particular, nine countries in this region belonged to the top-ten least restrictive countries.

As most countries, locally-incorporated foreign banks in Vietnam were discriminated against in the application of the common restrictions, as shown by the difference between TRI_FB and TRI_D. For example, foreign banks were not allowed to take local currency deposits from residents and onshore foreign bank branches not to open other transaction points outside their head offices.

For both domestic banks and locally-incorporated foreign banks in Vietnam, various administrative measures prevailed in banking operations in order to meet stabilization and socio-economic purposes. Such controls were applied to both deposit-taking and lending activities, foreign exchange business and network expansion. Banks found it difficult to mobilize funds as well as to make loans because of interest rate ceilings, targeted lending policy and some regulations discriminating against loans to the private sector. Interest rate ceilings caused non-transparent competition between banks; banks circumvented the cap on interest rates by charging up-front fees to borrowers and giving bonuses to depositors. Targeted lending was pervasive in state-owned banks, generating a crowding-out effect on private lending. Regulations discriminated against the granting of unsecured loans to private borrowers. For example, private enterprises must be profitable for two years in a row in order to qualify for unsecured loans from SOCBs (Leung, 2009). The most highly restricted activity was the foreign exchange business, where both price (exchange rate) and quantity (volume of transactions) were strictly controlled. SBV limited the number of branches a bank can establish by raising the paid-up capital requirement imposed on each additional branch (Dinh, 2012).

In Vietnam, the four SOCB dominated the whole financial system. In 2008, these banks made up 67\% of total banking assets and $61 \%$ of total credits to the economy. ${ }^{2}$ Given the SOCBs' well-documented inefficiency, ${ }^{3}$ their domination may hinder competition in the banking system and impede resource allocation in the economy as a whole. SOCBs could distort the extension of loans and the collection of deposits (Hawkins and Turner, 1999). This high concentration has also led to too-big-to-be-controlled and too-big-to-fail problems. In the early 2000s, the Government indeed had to bail out a number of

\footnotetext{
${ }^{2}$ Author's calculation, based on International Financial Statistics (IMF, 2009).

${ }^{3}$ Among the different bank groups, SOCBs have the highest non-performing loans rate and lowest rate of return on average assets (Dinh, 2011).
} 
SOCBs when their level of non-performing loans (NPLs) reached $80 \%$ and most of them were lossmaking (International Financial Corporation, 2008. In an effort of improving the efficiency of the SOCBs, the government has started the equitisation on these banks since 2006 and targeted to reduce its ownership share to $51 \%$ by 2010 ; however, the process is slow.

As with other Asian countries, such as China, India and Malaysia, Vietnam used a number of discriminatory restrictions, as shown by a big difference between TRI_FA and TRI_D. Foreign banks were discriminated against in terms of entry and operation. For example, in Vietnam, Thailand, Pakistan and Malaysia, foreign ownership was capped at $49 \%$ in a joint-venture bank. This limit restricted the scale of joint-venture banks, which may force them to incur additional real resource costs. For example, because of the equity capital limit, a joint-venture bank could not mobilize extra capital from its foreign counterpart for expanding operations. It must thus borrow from the Vietnamese market at higher interest rates. In addition, this measure was partly redundant and should be relaxed when fully foreign-owned banks have already been allowed. The Government still imposed a cap of 30\% on foreign purchases of shares in local banks in order to avoid the danger to domestic banks being taken over by foreign banks.

Figure 2 also highlights that Vietnam has reduced the degree of restrictiveness on locally-incorporated banks over time. The trade restrictiveness index for domestic banks fell to 0.26 in 2010 from 0.37 in 2006, whereas, in the same period, the index for locally-incorporated foreign banks declined to 0.24 from 0.38. Despite this reduction, the current level of restrictiveness is still high, even compared to OECD averages for the period 1997-2006. So there is still room for further reforms in Vietnam's banking industry.

\section{First-round impact of restrictions on banking industry \\ 3.1 Conceptual framework}

\section{Cost-escalating impacts}

Barriers to trade in banking services can increase real resource costs for banks (Llewellyn, 1986; Gowland, 1990; Benston and Kaufman, 1996). The key to this problem is that regulations might act as barriers limiting competition between service providers and preventing them from attaining economies of scale and scope. As a result, service providers may be discouraged from operating at their lowest possible costs (Warren and Findlay, 2000; Dee and Dinh, 2008; Dinh, 2013). This causes the supply curve to shift upward, increasing the unit cost of service and creating a wedge between costs "with" and "without" restrictions, as shown in Figure 3.

Figure 3 shows the banking market before and after the imposition of cost-escalating restrictions. Without restrictions, the banking market is in equilibrium at E0 with price $\mathrm{P} 0$ and output Q0. With costescalating restrictions, banks need to use more real resources in order to provide the same output as before, shifting the supply curve upwards, leading to a rise in the price to P1 and a fall in the output to Q1. The cost-escalating effects create a deadweight loss to society represented by the shaded area. This loss consists of a producer loss and a consumer loss. The producer loss comes from both increased real resource costs and reduced output, whereas the consumer loss results from both the increased price and reduced consumption quantity. Interestingly, in this case, there is a rise in the price but banks gain no price markup or economic rents.

\section{Rent-creating impacts}

Non-prudential regulations can also create rents for banks. In other words, these regulations may serve the interests of the regulated banks rather than customers (Llewellyn, 1986; Llewellyn, 1999; Benston and Kaufman, 1996). This is because some restrictions may create more market power for incumbent banks, enabling them to inflate the prices of financial services while the real resource costs remain unchanged. As a result, banks can obtain a higher price markup - economic rent. This rent is akin to a tax on consumers, which makes the supply curve shift upward, but the revenue flows to the incumbent banks rather than to the government (Dee, 2005). A typical example is that the interest rate ceiling may cause an artificial scarcity of credit supply, encouraging banks to charge borrowers extra fees in addition to interest rates, thereby creating a rent for banks. 
Figure 4 shows the banking market before and after the imposition of rent-creating barriers. Without restrictions, the banking market is in equilibrium at $\mathrm{E} 0$ with price $\mathrm{P} 0$ and output $\mathrm{Q} 0$. With rent-creating restrictions, banks can charge their customers a higher price at every output level, though there is no change in real resource costs. This is also equivalent to an upward shift in the supply curve, resulting in a new equilibrium E1. At this new equilibrium, there is a rise in the price to P1 and a fall in the output to Q1. The rent-creating measures create a deadweight loss to society as represented by the shaded triangular area in Figure 5. This loss also consists of a consumer loss and a producer loss. The consumer loss results from both the increased price and reduced consumption quantity, while the producer loss comes only from the reduced output. In this case, the banks gain all of the price markup (P1- P2) - or economic rents.

\subsection{Empirical results}

Dinh's (2013) study examines if barriers to trade in banking services either or both create rents and raising real costs. Her study uses a panel accounting data of 7,314 commercial banks in 28 countries over the period 1997-2006 from Bankscope (produced by Fithc IBCA) and the restrictiveness indices in banking services constructed by Dinh's (2008) study. Dinh adopts the Symmetric McFadden function forms of unit cost and unit profit as the key outcome variables as this functional form is flexible, parsimonious and regular. Dinh also applies the fixed effect regression models with treatment of serial correlation. Dinh's (2013) results show that restrictions on bank establishment and operation, such as licensing requirements, government ownership, and restrictions on movement of natural persons are statistically positive determinants of both cost and profit, at the $1 \%$ level of significance. In other words, restrictions on establishment and operation are both cost-escalating and rent-creating. Specifically, a one percentage point increase in the trade restrictiveness index on establishment and operation is estimated to raise total cost by $1.9 \%$ and to improve profit by $4.8 \%$. This findings enriches the current literature, which finds only rent-creating impacts of barriers to trade in banking services.

\section{Economy-wide impacts of trade reform in the Vietnamese banking industry \\ 4.1 Methodology}

In order to address the aim of the study and answer the research question, this paper takes the following research steps:

Calculation of banking services trade restrictiveness indexes. Calculating the banking services trade restrictiveness indexes for Vietnam and for the rest of the word in current policy settings and after trade reform in the banking industry using the template of measuring trade barriers in banking services and the weights (the relative importance of each restriction) produced in Dinh (2011) and Dinh (2013). The current paper focuses on the removal of restrictions that are currently in the process of reform and can be conducted in the next ten year, including: (i) equitisation of four SOCBs; (ii) removal of the interest ceilings; (iii) removal of administrative measures in banking services; (iv) removal of restrictions on foreign banks' establishment and operation; and (v) removing all restrictions on mode 4.

Calculation of the productivity and the tax equivalents. This is a crucial step in estimating the firstround effects, the productivity and the tax equivalents, of banking services trade barriers before and after trade reform using the regression results produced in Dinh (2013). The productivity equivalent is measured as the percentage change in total cost of bank operation due to cost-escalating barriers to trade in banking services compared with a scenarios without any barriers while the tax equivalent as the percentage change in the price mark-up caused by rent-creating barriers. As found in Dinh (2013), barriers to trade in banking services are found to increase bank cost and profits, therefore are modelled as an increase in the productivity and tax equivalents, respectively.

Application of FTAP model. As in Dinh's (2012) study, we also use the FTAP model - a comparative static, computable general equilibrium model of the world economy that is developed in stages from the GTAP model in order to measure the long-term economy-wide employment impacts of trade reform in the Vietnamese banking industry (Hanslow et al., 2000). The key contribution of FTAP to GTAP is the former includes a treatment of foreign direct investment, thus making possible to differentiate the impacts of liberalisation restrictions on domestic banks from foreign ones. The FTAP model features 
firm-level product differentiation with large-group monopolistic competition and increasing returns to scale. It also allows for capital accumulation and international borrowing and lending. As employment as the focus of this study, rather than fixing total employment as in few studies on economy-wide impacts of services trade liberalisation (e.g., Dinh, 2012; Verikios and Zhang, 2000), the present study allows for the total employment in the economy to change. The application of the FTAP model is as follows:

Model data base preparation. For research purposes and given limited data of sector-specific foreign ownership shares in Vietnam, the GTAP 7 database is aggregated into two regions (Vietnam and the rest of the world), and 32 sectors (for more details, refer to Table A1, Appendix). As the GTAP database aggregate banks with other financial intermediaries, so the present study treats the banking services as universal to the whole financial sector. Given the dominance of the banking industry in the financial sector in Vietnam, this treatment is likely to give reliable results. Following Dee (2010), the study imputes FDI firms' activities using data on bilateral FDI stocks for the rest of the world in Boumellassa et al. (2007) and Vietnam's FDI data from Vietnam's General Statistics Office.

Injection of current barriers estimates. As the GTAP model does not reflect prevailing trade barriers in banking services, so we will inject the tax equivalent in the banking industry of Vietnam and the rest of the world into the model. In this study, the tax equivalent is injected into the model as an implicit output tax and the rents from this tax shock follows to the banking industry rather than to the government. For foreign invested firms, a part of this rent is modelled to be taxed before going back to their home countries. The productivity equivalent does not need to be injected into the model at this stage as it is inherent in bank cost structures.

Simulation. This final step is to simulate the effects of the trade reform in the banking industry on sectoral employment and total employment in the Vietnamese economy. In this model, this trade reform is modelled as a reduction in the output tax and a gain in the technical change in the financial industry. The simulation is conducted into two macroeconomic settings: fixed versus variable total employment (labour supply). The first macroeconomic setting enables us to examine the reallocation of employment between industries in the economy under trade reform while there is no change in the total national employment (equivalently a fixed labour supply). The second setting additionally shows if trade reform would change the total employment (equivalently a variable labour supply). In all settings, labour is assumed to be perfectly mobile between industries within region while capital is imperfectly mobile between industries within region and between regions.

\subsection{Data}

Trade restrictiveness indexes. Tables 1 and 2 present the key data for simulation which are generated using the aforementioned methodology. This includes the trade restrictiveness indexes in establishment and operation (TRI_E and TRI_O) separately for domestic banks and foreign ones in Vietnam before and after each trade reform. The table also shows the corresponding productivity and the tax equivalents (PE and TE). Compared with Dinh's (2012), the data for simulation in the present study is somewhat different. First, the input data on the current policy setting in the present paper is higher as the imposition of interest ceilings is included as a restriction rather than being taken out as a case of policy retrograde steps as in Dinh's (2012) paper. Second, the present paper additionally includes the removal of restrictions on mode 4 into trade reform. As in Dinh's (2012), the paper assumes no change in trade barriers as well as the productivity and the tax equivalents for the rest of the world after trade reform in the Vietnamese banking industry.

Employment structure before simulation. Table 3 shows the employment structure by industry and sector in Vietnam before simulation using GTAP7 Database. All 32 aggregated industries create jobs for around 17 million people, $76 \%$ of which are unskilled labour, slightly higher than ASEAN countries (except Vietnam) on average (73\%). Among sectors, services contribute the most to total employment (43\%), then followed by manufacturing (36\%) and agriculture and mining (21\%). Services also attract most skilled labour (74\%), similar to ASEAN's. Compared with ASEAN countries, Vietnam is labourintensive with the ratio of labour-capital being 1.3 compared with 0.76 for ASEAN. Domestic firms account for $81 \%$ of total employment although they make up $65 \%$ total capital. The financial services industry takes up $4 \%$ of total employment or $8 \%$ of the services sector's employment. 
The linkages of the financial services industry with other industries. As shown in Table 4, financial services are inputs for all industries, its share of the industry total cost ranges from $0.1 \%$ to $28.4 \%$. The five industries with the highest share of financial services as inputs are coal, oil and gas mining $(28.4 \%)$; petroleum, coal products $(16 \%)$; communication $(15 \%)$; trade $(8.5 \%)$; recreational and other services $(8.0 \%)$. The industries that use relatively least financial services are water transport $(0.1 \%)$; electricity and gas production and distribution $(0.3 \%)$; paper products, publishing $(0.4 \%)$; other mining $(0.4 \%)$; and transport equipment $(0.7 \%)$.

The five largest customers of the financial industry (measured by the share of the financial industry's output) are coal, oil and gas mining (28.2\%); public administration, defence, education and health $(8.8 \%)$; trade (5.4\%); food and beverages and tobacco manufacture $(5.4 \%)$; and leather products $(4.9 \%)$. Its five smallest customers are water transport $(0.04 \%)$; other mining $(0.06 \%)$; water $(0.07 \%)$; forestry $(0.2 \%)$; paper products, publishing $(0.3 \%)$.

\subsection{Results and Discussions}

This section first discusses how trade reform under two different macroeconomic settings (fixed versus variable labour supply) would impact the industry output in the long run. It then examines the changes in: (i) the industry output; (ii) the industry output price; (iii) the labour and capital prices; (iv) the industry employment; and (v) the allocation of the increased employment.

\subsubsection{Projected output changes (Table 5)}

Regardless of whether the labour supply is fixed or not, trade reform in the banking industry would create the highest output expansion in the financial services industry. This occurs as trade reform leads to a reduction in the output tax and a productivity gain in the financial services industry. A decline in the output tax imposed on financial services would reduce the price markup, equivalent to an expansion in the supply; a productivity gain leads to a reduction in total production cost, which also raises the supply. Both shocks lead to an expansion in the financial services industry and a lowered output price, however, FDI institutions enjoy a higher expansion as they receive a larger price markup decline and a higher productivity improvement from trade reform as shown in Table 2. Compared with the case of a fixed labour supply, the output expansion in the financial services is larger under a variable labour supply as any increased labour demand for expansion in this industry can be met by an increased labour supply rather than just moving labour from other industries.

The expansion of the financial firms also triggers an expansion or a contraction of other industries through spill-over effects. As shown in Table 4, the financial industry acts as both a buyer and seller to any other industry. The expansionary effect on other industries thus occurs in two ways. First, the expansion of the financial firms would increase their demand for other industries' outputs. Second, the financial industry expansion implies a decline in their output prices, thereby reducing the production cost of all other industries using financial services as inputs. However, the expansion in the financial industry can also cause a contractionary (crowding-out) effect on other industries as if the expansion attracts factors including labour from other industries to the financial industry. If an industry observes a dominance of the expansionary effect over the contractionary effect, then it will experience an expansion or a contraction otherwise. In the case of a fixed labour supply, moving labour from other industries to the financial industry is the only way to meet this industry's higher demand for labour; thus causing an expansion in seven industries and a contraction in 25 ones. Three top expansionary industries apart from the financial services are petroleum, coal products; air, land transport; and insurance while three with the highest contraction are other business services; transport equipment nec; and iron, steel and non-ferrous metals. When the labour supply is variable, in the long run, the increased demand for labour in any industries can also be met by the labour force expansion, the contractionary effect is thus smaller and dominated by the expansionary effect. An expansion is thus observed in all industries, especially in petroleum, coal products; public administration, defence and education; air, land transport. Overall, trade reform would raise the total output in the economy by $1.5 \%$ with a fixed labour supply and by $5.6 \%$ with a variable labour supply. 
Domestic versus FDI firms. In all simulations, in expanding industries, FDI firms expand slightly more than their domestic counterparts. In case of a fixed labour supply, in contracting industries, FDI firms suffer a little less contraction than their domestic counterparts.

\subsubsection{Projected output price changes (Table 6)}

In all settings, the output prices in the financial services sector decline the most in both domestic and FDI institutions as they enjoy the highest output expansion. As expected, trade reform leads to a larger decline in the market price of FDI services than that of domestic ones as the former expand more than the latter as shown above.

Trade reform also impacts on the other industries' output prices through both supply and demand. From the demand perspective, trade reform raises the demand for the other industries' output, which in turn increases their output price. From the supply perspective, trade reform can have competing effects. On the one hand, trade reform reduces the total production cost of other industries, thereby reducing their market price. On the other hand, the crowding out effect of the financial services leads to a contraction in other industries, thereby increasing their market price. If the expansion in the supply is big enough to outweigh the crowding-out effect and the demand expansion then a lower market price will be observed and vice versa. In the case of a fixed labour supply, a price rise is observed in all 25 contraction industries and a price fall in seven expansionary industries. When the labour supply is variable, the output price declines in 25 industries with a dominant expansionary supply effect, but increases in other seven industries with a dominant expansionary demand effect.

Domestic versus FDI firms. In all simulations, in all industries, there is a growth in the relative price of domestic to FDI products, as measured by the difference in the percentage change in the price of domestic products and that of FDI products. In other words, FDI products are relatively cheaper than domestic ones after trade reform.

\subsubsection{Projected wage and capital price changes (Tables 7 and 8)}

In all simulations, there is a uniform change in the price of labour in both domestic and FDI firms across the industries (Table 7). This is because both domestic and FDI firms are assumed to share the same cost structure and labour is perfectly mobile between industries. When total labour supply is fixed, an excessive demand for labour is only met by freely attracting labour from other industries until the labour market clears, leading to a uniform increase in the price of each labour type (unskilled labour: 2.35\%; skilled labour: $3.74 \%$ ). The higher increase in the price of skilled labour comes from the fact that the financial sector uses relatively more skilled labour than the economy on average (the ratio of skilled labour to unskilled labour for the financial services is more than double the ratio for the economy as a whole); so an expansion in this sector driven by trade reform would lead to a higher demand for skilled labour relative to unskilled labour. Given the relative shortage of skilled labour ${ }^{4}$ in Vietnam and the position of the financial sector as the third highest user of skilled labour, ${ }^{5}$ a higher demand for skilled labour results in a higher increase in wages for skilled labour relative to unskilled labour. In other words, skilled labour becomes relatively more expensive than unskilled labour. When total labour supply is variable and perfectly mobile, an excessive demand for labour can be also met by an increase in the labour force until the labour market clears, thus causing a uniform decline in the labour price by $0.31 \%$.

In all simulations, capital is assumed to be accumulated and imperfectly mobile, the changes in capita prices are thus substantially different across industries. However, the changes are quite similar between domestic and FDI firms within industries as these firms share the same cost structure. A rise in the capital price is observed in 24 industries for the case of the fixed labour supply and in 31 industries for the case of the variable labour supply.

The percentage change in the relative price of labour to capital, as measured by the difference in the percentage change in the labour price and that in the capital price, is shown in Table 8 . In the case of the fixed labour supply, trade reform leads to a rise in the relative price of both unskilled labour and

\footnotetext{
${ }^{4}$ Skilled labour accounts for only $24 \%$ of total labour costs for the country as a whole. This implies that the share of skilled labour in the total labour force is even lower than $24 \%$.

${ }^{5}$ Only public administration, defences, education, health and energy sectors have higher shares.
} 
skilled labour to capital in nearly two thirds of 32 industries, which means labour being relatively more expense than capital. Ten industries (notably financial services; petroleum, coal products; and insurance) observe the reduction in the relative price of unskilled labour to capital. In the case of the variable labour supply, the relative price of both labour types to capital reduce in all industries, which means labour being relatively cheaper than capital.

\subsubsection{Projected employment growth by industry (Table 9)}

Fixed labour supply. Trade reform would expand employment in eight industries and simultaneously contract jobs in other 24 industries so that total employment maintains unchanged. Amongst the eight expanding industries, five are in services, two in manufacturing and one in agriculture and mining. Apart from the financial services, the three industries with the highest employment growth are petroleum and coal products $(10.8 \%)$, air and land transport $(4.3 \%)$, and insurance $(3.5 \%)$. These most-expanding industries have relatively strong linkages with the financial services as measured in terms of share of financial services in their total cost, so the expansion of the financial services would directly benefit these industries through lower market prices of financial services. Their expansion would also benefit each other through their close linkages, for example, petroleum and coal products account for $80 \%$ of total non-labour cost in the air, land transport. In addition, as shown in Table 8, these industries experience the highest reduction in the relative price of labour to capital, so would substitute labour for capital in order to minimise total production cost. The most job contraction would be observed in business services (-7.5\%); iron, steel and non-ferrous metals (-5.4\%); and transport equipment (-5.1\%); these industries have low linkages with the financial sectors and experience the highest growth in the relative price of labour to capital. On average, services would enjoy a job expansion while agriculture, mining and manufacturing would suffer a job contraction.

With a fixed labour supply, trade reform would lead to a higher increase in wages for skilled workers than unskilled workers as shown before. This would encourage a substitution of unskilled labour for skilled labour across industries. As a result, in contracting sectors, the employment of skilled workers would decline more than that for unskilled labour. In expanding industries, there would be a slower growth of skilled employment relative to unskilled labour. The proportion of skilled labour in total industry employment would reduce in all industries, especially in skilled-labour intensive ones.

Variable labour supply. Trade reform with a variable labour supply sector would expand employment in the financial industry itself and all other industries through flow-on effects, thereby raising total employment by $1,086,710(6.3 \%)$. This trade reform creates 196,640 extra jobs for the financial industry itself but 890,070 extra jobs for the other industries. In other words, one extra job in the financial industry is linked with nearly five extra jobs in other industries. Eighteen industries would expand more than the total employment growth, seven of which taking up a third of total employment are skilledlabour-intensive. These more-than-average expanding industries would also experience the highest reduction in the relative price of labour to capital (Table 8). As in the case of fixed labour supply, the highest employment growth would be observed in similar industries but at a much larger extent, such as financial services $(32.2 \%)$; petroleum and coal products $(24.2 \%)$; insurance $(13.1 \%)$; air, land and transport (12.7\%); moto vehicles and parts (10.4\%), three in the services sector and two in the manufacturing sector. The least expansion would be observed in other mining $(0.5 \%)$; construction $(0.7 \%)$; and agriculture $(0.9 \%)$ - those with the lowest reduction in the relative price of labour to capital. On average, employment would grow the most in services (8.8\%), followed by manufacturing $(6.3 \%)$, and agriculture and mining (1.1\%).

With a variable labour supply, all increased demand for labour would be fully met by the increased labour supply. As a result, the employment growth in all industries would be the same for both unskilled and skilled labour, thereby preserving the ratio of unskilled to skilled labour.

Domestic vs. FDI firms. In all simulations, FDI firms seem to be more advantaged than domestic counterparts. Regardless of a fixed or variable labour supply, in expanding industries, the employment growth for both unskilled and skilled labour is higher in FDI firms than in domestic fellows as the former experiences a higher output expansion than the latter. In contracting industries which only happens in the case of a fixed labour supply, the employment of both labour types declines at a lower 
rate for FDI firms than for domestic counterparts as the former suffer a lower output contraction than the latter.

\subsubsection{Change in the employment structure (Table 10)}

Table 10 presents the change in the employment structure by industry. In all simulations, trade reform relocate labour towards the services sector. The services sector increases its employment share by $0.6 \%$ with a fixed labour supply and by $1 \%$ with a variable labour supply.

Fixed labour supply. In case of a fixed labour supply, trade reform would expand the employment share of the eight expanding sectors. The three industries with the highest increase in their employment share would be financial services $(0.78 \%)$; petroleum, coal products $(0.06 \%)$; and coal, oil, gas mining $(0.04 \%)$. A contraction in the employment share would be observed the most in other business services $(-0.34 \%)$, chemical, rubber, plastic products $(-0.16 \%)$; textiles $(-0.12 \%)$; and transport equipment ($0.12 \%$ ). In general, there would be a movement of labour from the manufacturing sector to the services sector, resulting in a higher employment share of the former and a lower share of the latter.

Variable labour supply. In case of a variable labour supply, trade reform would lead to an improvement of the employment share of the 19 sectors that expand employment more than the total employment growth. The five industries with the highest increase in their employment share are financial services $(0.86 \%)$; public administration and defence, education and health $(0.23 \%)$; electricity and gas production and distribution $(0.17 \%)$; petroleum, coal products $(0.09 \%)$; and recreational and other services $(0.08 \%)$. A contraction in employment share would be observed the most in agriculture production $(-0.68 \%)$, construction $(-0.37 \%)$, coal, oil, gas mining $(-0.2 \%)$; food and beverages and tobacco $(-0.12 \%)$; transport equipment and forestry $(-0.07 \%)$.

Under a variable labour supply, of the 1,086,710 increased jobs, the services sector would offer the most $(60 \%)$, followed by manufacturing (36\%) and agriculture and mining $(4 \%)$. The five industries generating the most employment for the increased labour supply are public administration, defence, education and health (18.7\%), financial services (18.1\%); electricity and gas production and distribution (10\%); food and beverages and tobacco manufacture (5.1\%), business services (4.32\%). The five industries that would attract the least the increased labour are other mining $(0.02 \%)$, water transport $(0.09 \%)$, forestry $(0.22 \%)$; water $(0.28 \%)$, and insurance $(0.54 \%)$.

\subsection{Conclusions}

Using the FTAP-VN model and GTAP 7 Database, the paper finds that potential trade reform in Vietnam's banking industry could have significant impacts on employment across industries in the economy regardless of the labour supply assumptions. In case of a fixed labour supply, trade reform would create jobs in eight industries including the financial services itself, while simultaneously contracting employment in the other 24 industries. In case of a variable labour supply - a more realistic assumption that captures the redundancy of labour in the informal labour market and the population growth, the paper shows that trade reform could expand jobs in all industries, thereby increasing total employment by $1,086,710(6.3 \%)$. In other words, one extra job in the financial industry is linked with nearly five extra jobs in other industries.

In both labour supply assumptions, trade reform would most benefit employment in the financial services itself and the industries with close linkages with the financial sector and facing the highest reduction in the relative price of labour to capital. In any cases, services would gain the most in terms of job creation from the trade reform. Services would also absorb most of the increased labour supply, followed by manufacturing and agriculture and mining. In all simulations, FDI firms seem to receive a higher employment gain and suffer less employment loss than domestic firms. Regardless of a fixed or variable labour supply, in expanding industries, the employment growth for both unskilled and skilled labour is higher in FDI firms than in domestic fellows as the former experiences a larger output expansion than the latter. In contracting industries which only happens in the case of a fixed labour supply, the employment of both labour types declines at a lower rate for FDI firms than for domestic counterparts as the former suffers a smaller output contraction than the latter. 
With a fixed labour supply, trade reform would encourage a substitution of unskilled labour for skilled labour across industries, placing skilled labour in a relatively disadvantaged position in the short run. In the next few years, in order to avoid a shortage of skilled labour and consequent pressure on wages, Vietnam would need to invest in education and training to create a better skilled labour force, particularly in banking and finance. With a variable labour supply, in the long-run, the pressure on wage increase and substitution of skilled labour for unskilled labour could be mitigated with the transformation of unskilled labour into skilled labour and the increasing labour supply.

The projected results in this paper need to be interpreted with some caveats given our modelling features. We assume full employment of labour and perfectly mobile labour in the long run. In a developing countries like Vietnam, in the short-term, it is likely that unemployment is high and there are transaction costs of moving labour (especially unskilled labour) from one sector to another, so labour is not perfectly mobile. The employment change due to trade reform in the short run is thus likely smaller than the projected results in the long run. In addition, under a variable labour supply assumption, we assume that the ratio of skilled to unskilled labour is preserved before and after trade reform. In the long run, with the technology improvement, education and training, skilled labour will be employed relatively more than unskilled labour. Further research that takes into account unemployment, unskilled labour immobility and increased ratio of skilled to unskilled labour is thus needed. 
Figure 1. Trade restrictiveness of banking services of other regions, average 1997-2006

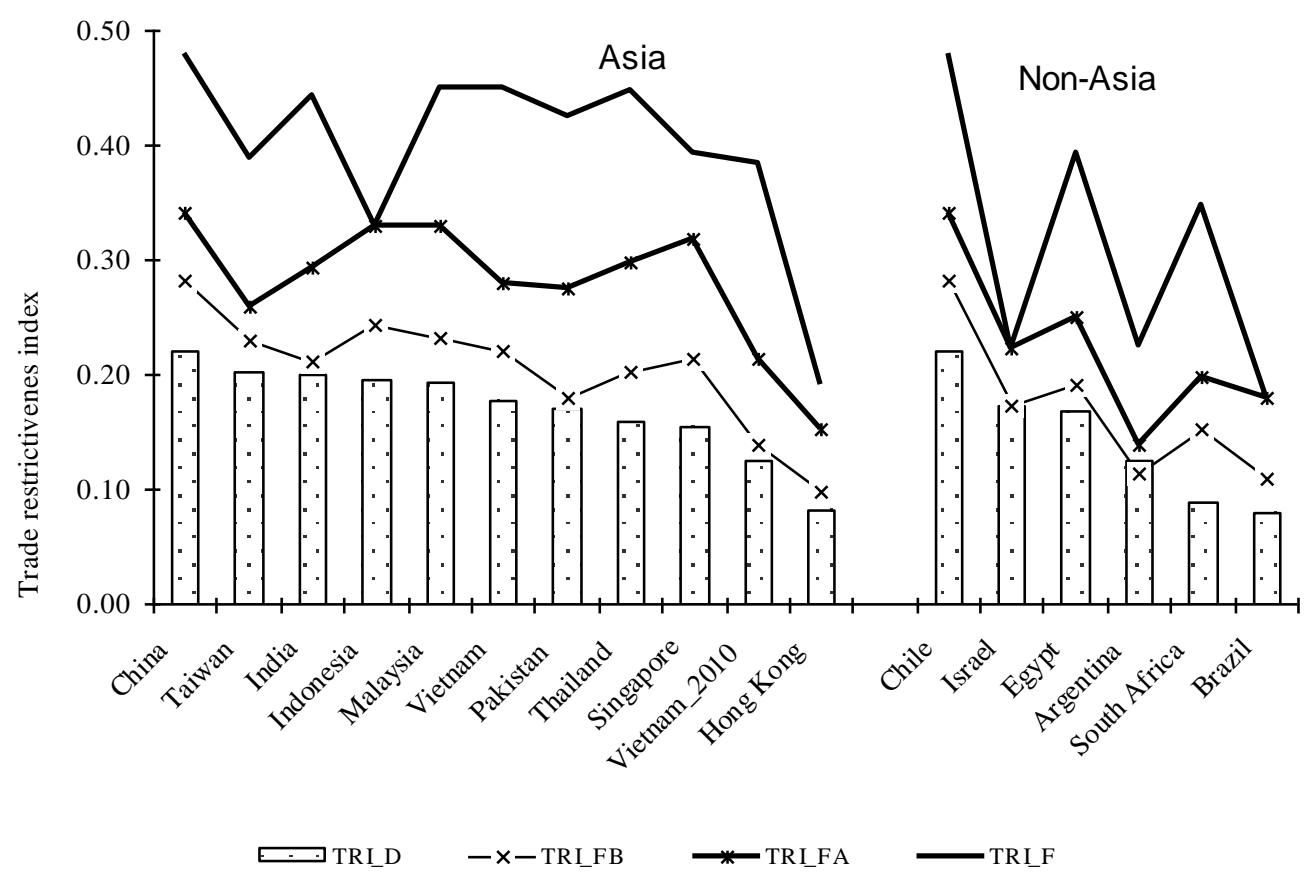

Note: For every country, the trade restrictiveness index is averaged over the period 1997-2006. For Vietnam, the trade restrictiveness indexes are also calculated for 2010, labelled as Vietnam_2010.

TRI_D: Trade restrictiveness index for domestic banks

TRI_FB: Trade restrictiveness index for locally-incorporated foreign banks using common restrictions TRI_FA: Trade restrictiveness index for locally-incorporated foreign banks

TRI_F: Trade restrictiveness index for foreign banks

Source: Dinh (2011). 
Figure 2. Trade restrictiveness of banking services in OECD countries, average 1997-2006

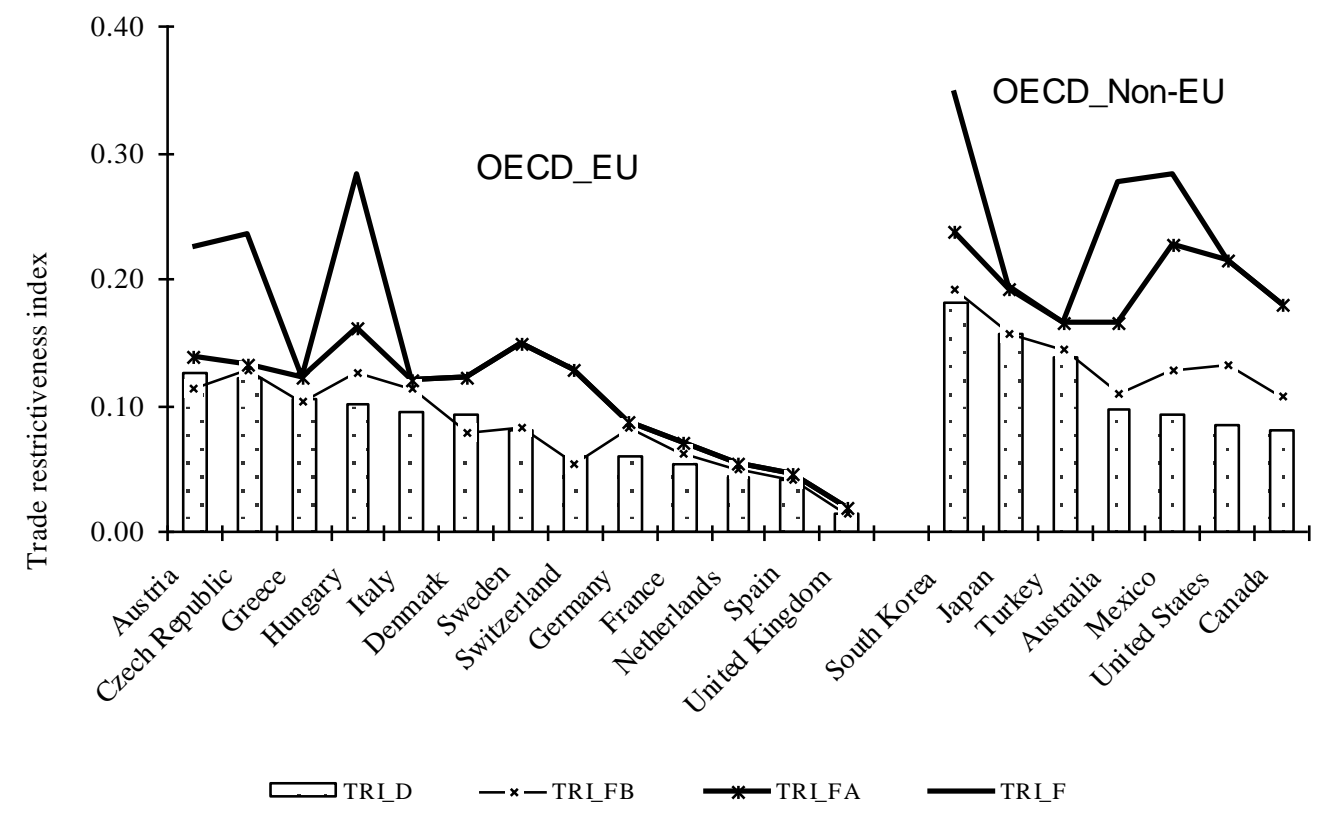

TRI_D: Trade restrictiveness index for domestic banks

TRI_FB: Trade restrictiveness index for locally-incorporated foreign banks using common restrictions TRI_FA: Trade restrictiveness index for locally-incorporated foreign banks

TRI_F: Trade restrictiveness index for foreign banks

Note: For every country, the trade restrictiveness index is averaged over the period 1997-2006. For Vietnam, the trade restrictiveness indexes are also calculated for 2010, labelled as Vietnam_2010.

Source: Dinh (2011). 
Figure 4. The cost-escalating effects of trade barriers in banking services

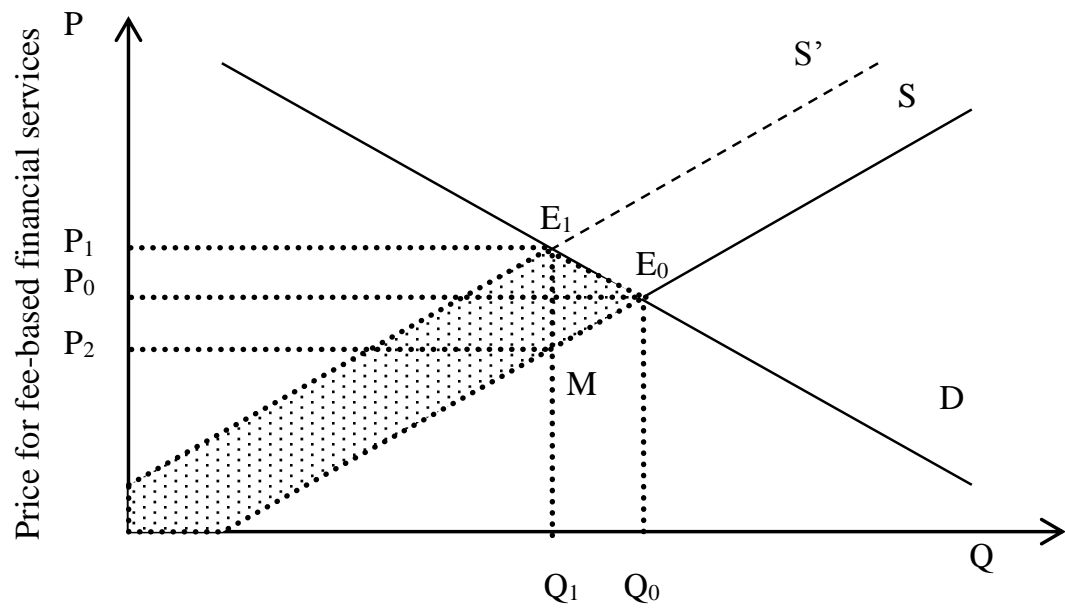

Volume of financial services

Source: Dinh (2011) 
Figure 5. Rent-creating impacts of trade barriers in banking services

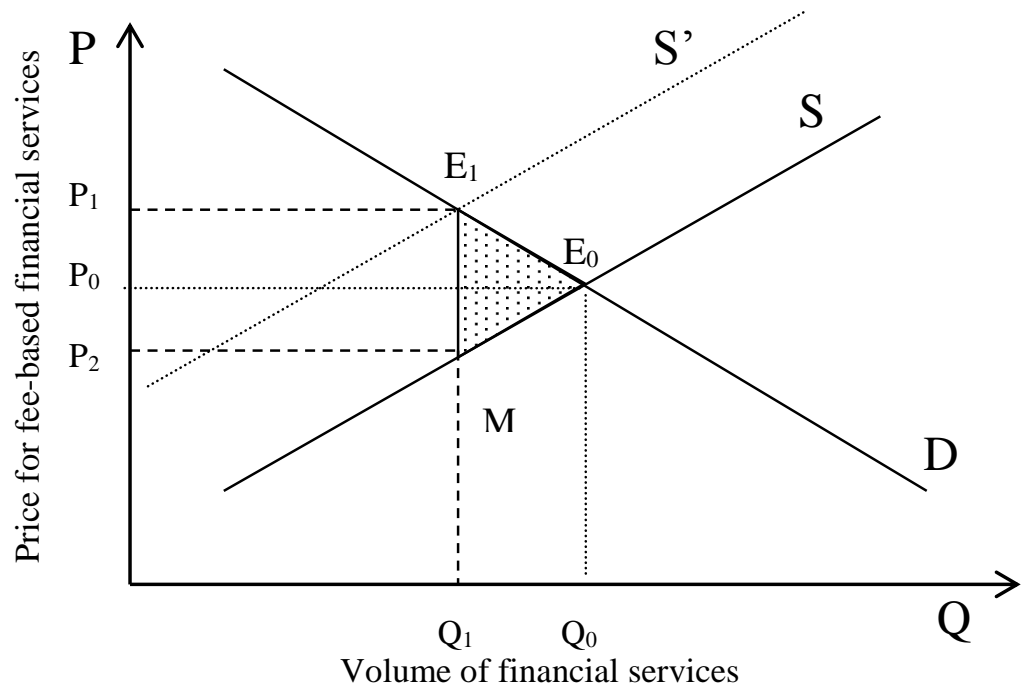

Source: Dinh (2011) 
Table 1. Levels of trade restrictiveness indexes, productivity and tax equivalents in Vietnam before and after the banking's trade reform

\begin{tabular}{|c|c|c|c|c|c|c|}
\hline & \multicolumn{3}{|c|}{ Domestic banks } & \multicolumn{3}{|l|}{ Foreign banks } \\
\hline & $\begin{array}{l}\text { Trade } \\
\text { restrictiveness } \\
\text { index } \\
\end{array}$ & $\begin{array}{l}\text { Productivity } \\
\text { equivalent }\end{array}$ & $\begin{array}{l}\text { Tax } \\
\text { equivalent }\end{array}$ & $\begin{array}{l}\text { Trade } \\
\text { restrictiveness } \\
\text { index }\end{array}$ & $\begin{array}{l}\text { Productivity } \\
\text { equivalent }\end{array}$ & $\begin{array}{l}\text { Tax } \\
\text { equivalent }\end{array}$ \\
\hline $\begin{array}{l}\text { Current policy settings } \\
\text { Reducing barriers to establishment }\end{array}$ & 0.085 & 15.9 & 8.7 & 0.174 & 32.6 & 15.6 \\
\hline $\begin{array}{l}\text { After eliminating restrictions on licensing, and } \\
\text { reducing screening and approval requirements }\end{array}$ & 0.069 & 12.9 & 7.2 & 0.162 & 30.3 & 14.7 \\
\hline After equitisation & 0.080 & 14.9 & 8.2 & 0.169 & 31.6 & 15.2 \\
\hline After removing the foreign ownership cap & 0.085 & 15.9 & 8.7 & 0.157 & 29.3 & 14.3 \\
\hline Reducing barriers to operation & & & & & & \\
\hline After removing restrictions on operation & 0.048 & 9.0 & 5.2 & 0.101 & 19.0 & 10.1 \\
\hline After removing mode 4 restrictions & 0.085 & 15.9 & 8.7 & 0.135 & 25.2 & 12.8 \\
\hline After reimposing ceiling rates & 0.074 & 13.8 & 7.7 & 0.163 & 30.5 & 14.8 \\
\hline After all trade reforms & 0.015 & 2.8 & 1.7 & 0.015 & 2.8 & 1.7 \\
\hline
\end{tabular}

Source: Author's calculation 
Table 2. Change in trade restrictiveness indexes, productivity and tax equivalents in Vietnam arising from the banking's trade reform

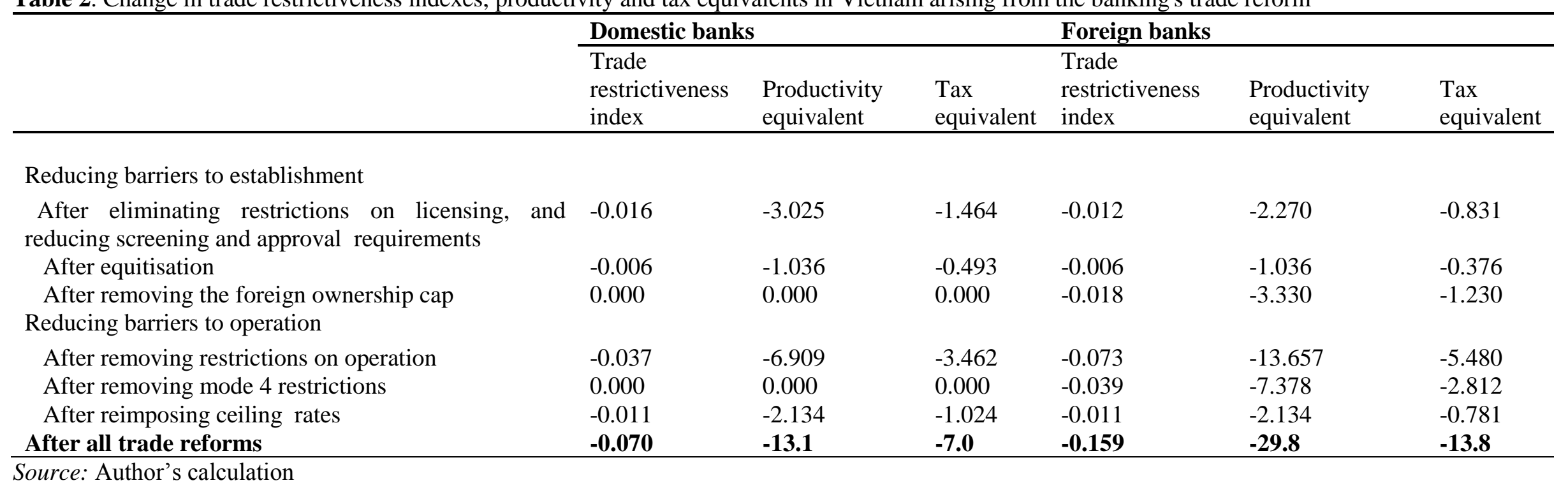

Source: Author's calculation 
Table 3. Vietnam's employment structure before trade reform, GTAP7 Database

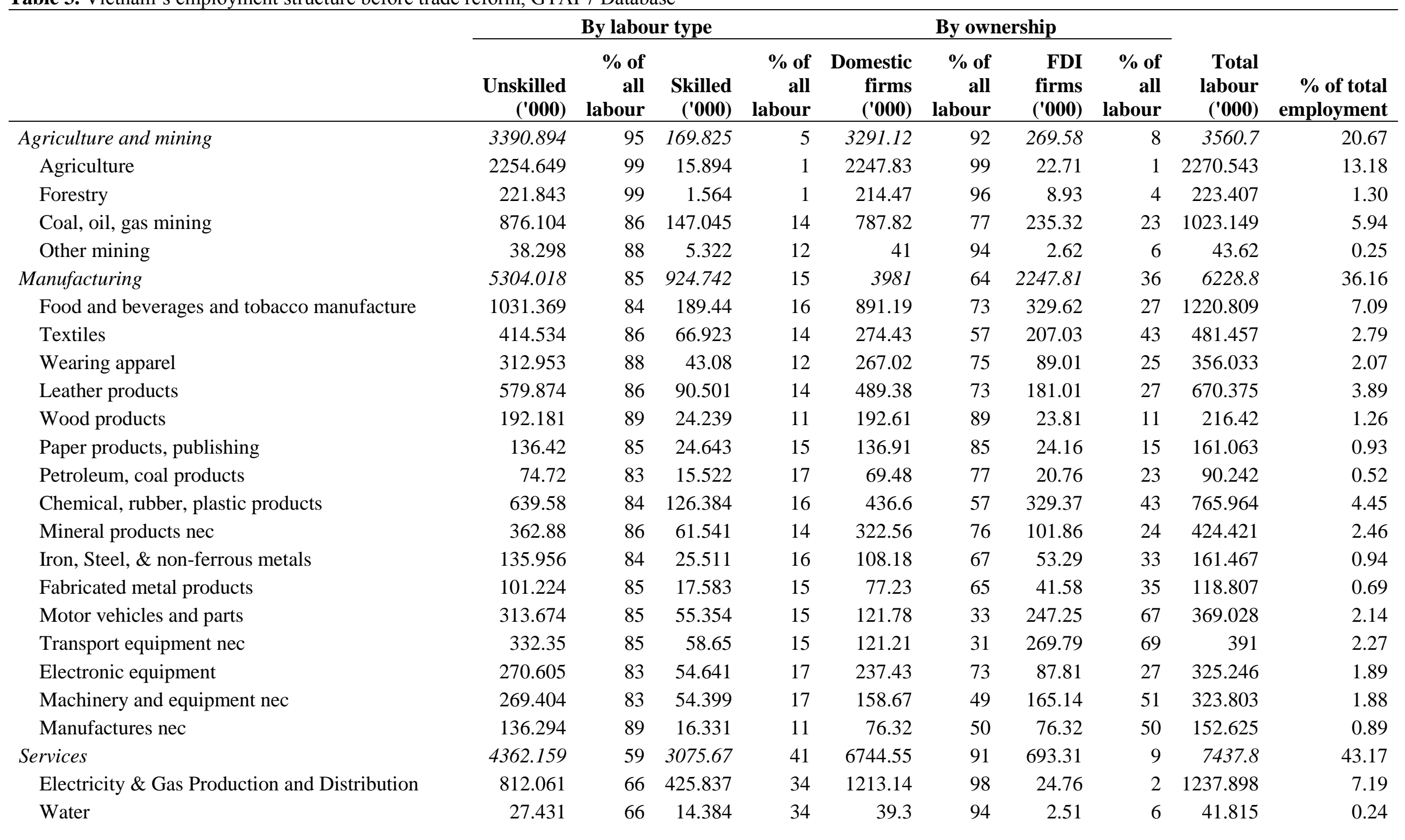




\begin{tabular}{|c|c|c|c|c|c|c|c|c|c|c|}
\hline & \multicolumn{4}{|c|}{ By labour type } & \multicolumn{4}{|c|}{ By ownership } & \multirow[b]{2}{*}{$\begin{array}{r}\text { Total } \\
\text { labour } \\
(' 000)\end{array}$} & \multirow[b]{2}{*}{$\begin{array}{r}\% \text { of total } \\
\text { employment }\end{array}$} \\
\hline & $\begin{array}{r}\text { Unskilled } \\
(' 000) \\
\end{array}$ & $\begin{array}{r}\% \text { of } \\
\text { all } \\
\text { labour }\end{array}$ & $\begin{array}{r}\text { Skilled } \\
(' 000)\end{array}$ & $\begin{array}{r}\% \text { of } \\
\text { all } \\
\text { labour }\end{array}$ & $\begin{array}{r}\text { Domestic } \\
\text { firms } \\
(' 000)\end{array}$ & $\begin{array}{r}\% \text { of } \\
\text { all } \\
\text { labour }\end{array}$ & $\begin{array}{r}\text { FDI } \\
\text { firms } \\
(' 000)\end{array}$ & $\begin{array}{r}\% \text { of } \\
\text { all } \\
\text { labour }\end{array}$ & & \\
\hline Construction & 1008.765 & 85 & 182.221 & 15 & 1167.17 & 98 & 23.82 & 2 & 1190.986 & 6.91 \\
\hline Trade & 187.11 & 82 & 41.911 & 18 & 75.58 & 33 & 153.44 & 67 & 229.021 & 1.33 \\
\hline Air, land transport & 69.901 & 82 & 15.657 & 18 & 74.43 & 87 & 11.13 & 13 & 85.558 & 0.50 \\
\hline Water transport & 21.795 & 82 & 4.882 & 18 & 21.35 & 80 & 5.34 & 20 & 26.677 & 0.15 \\
\hline Communication & 127.684 & 59 & 87.998 & 41 & 211.37 & 98 & 4.31 & 2 & 215.682 & 1.25 \\
\hline Financial services nec & 361.574 & 59 & 249.193 & 41 & 555.8 & 91 & 54.97 & 9 & 610.767 & 3.55 \\
\hline Insurance & 26.746 & 59 & 18.433 & 41 & 24.85 & 55 & 20.33 & 45 & 45.179 & 0.26 \\
\hline Other business services & 461.547 & 59 & 318.07 & 41 & 421 & 54 & 358.62 & 46 & 779.617 & 4.53 \\
\hline $\begin{array}{l}\text { Recreational and other services } \\
\text { Public administration and defence, education, }\end{array}$ & 255.758 & 59 & 176.265 & 41 & 423.38 & 98 & 8.65 & 2 & 432.023 & 2.51 \\
\hline health & 1001.787 & 39 & 1540.82 & 61 & 2517.18 & 99 & 25.43 & 1 & 2542.607 & 14.76 \\
\hline Total & 13057.07 & 76 & 4170.24 & 24 & 14016.7 & 81 & 3210.7 & 19 & 17227.3 & $\mathbf{1 0 0 . 0 0}$ \\
\hline
\end{tabular}


Table 4. The linkages of the financial industry in the economy before trade reform

\begin{tabular}{lrr}
\hline & $\begin{array}{l}\text { Share of financial } \\
\text { services in total } \\
\text { production cost }\end{array}$ & \multicolumn{2}{c}{$\begin{array}{l}\text { Share of total } \\
\text { financial services' } \\
\text { output }\end{array}$} \\
\hline Agriculture & 0.47 & 2.69 \\
Forestry & 0.46 & 0.21 \\
Coal, oil, gas mining & 7.77 & 28.23 \\
Other mining & 0.31 & 0.06 \\
Food and beverages and tobacco manufacture & 0.91 & 5.36 \\
Textiles & 0.58 & 1.56 \\
Wearing apparel & 0.87 & 3.00 \\
Leather products & 1.03 & 4.89 \\
Wood products & 1.07 & 1.29 \\
Paper products, publishing & 0.32 & 0.28 \\
Petroleum, coal products & 7.51 & 1.50 \\
Chemical, rubber, plastic products & 0.75 & 2.54 \\
Mineral products nec & 0.79 & 1.53 \\
Iron, Steel, \& non-ferrous metals & 0.93 & 1.19 \\
Fabricated metal products & 1.49 & 0.66 \\
Motor vehicles and parts & 1.31 & 2.08 \\
Transport equipment nec & 0.44 & 0.47 \\
Electronic equipment & 0.81 & 1.77 \\
Machinery and equipment nec & 1.41 & 2.40 \\
Manufactures nec & 0.99 & 0.95 \\
Electricity \& Gas Production and Distribution & 0.12 & 0.34 \\
Water & 0.92 & 0.07 \\
Construction & 1.03 & 4.86 \\
Trade & 5.96 & 5.42 \\
Air, land transport & 2.71 & 2.76 \\
Water transport & 0.10 & 0.04 \\
Communication & 3.48 & 1.51 \\
Financial services nec & 6.86 & 8.07 \\
Insurance & 3.39 & 0.58 \\
Other business services & 0.56 & 0.55 \\
Recreational and other services & 4.18 & 4.34 \\
Public administration and defence, education, & & \\
health & 2.67 & 8.81 \\
\hline & &
\end{tabular}

Source: Author's calculation from GTAP 7 Database 
Table 5. The change in the industry output (\%)

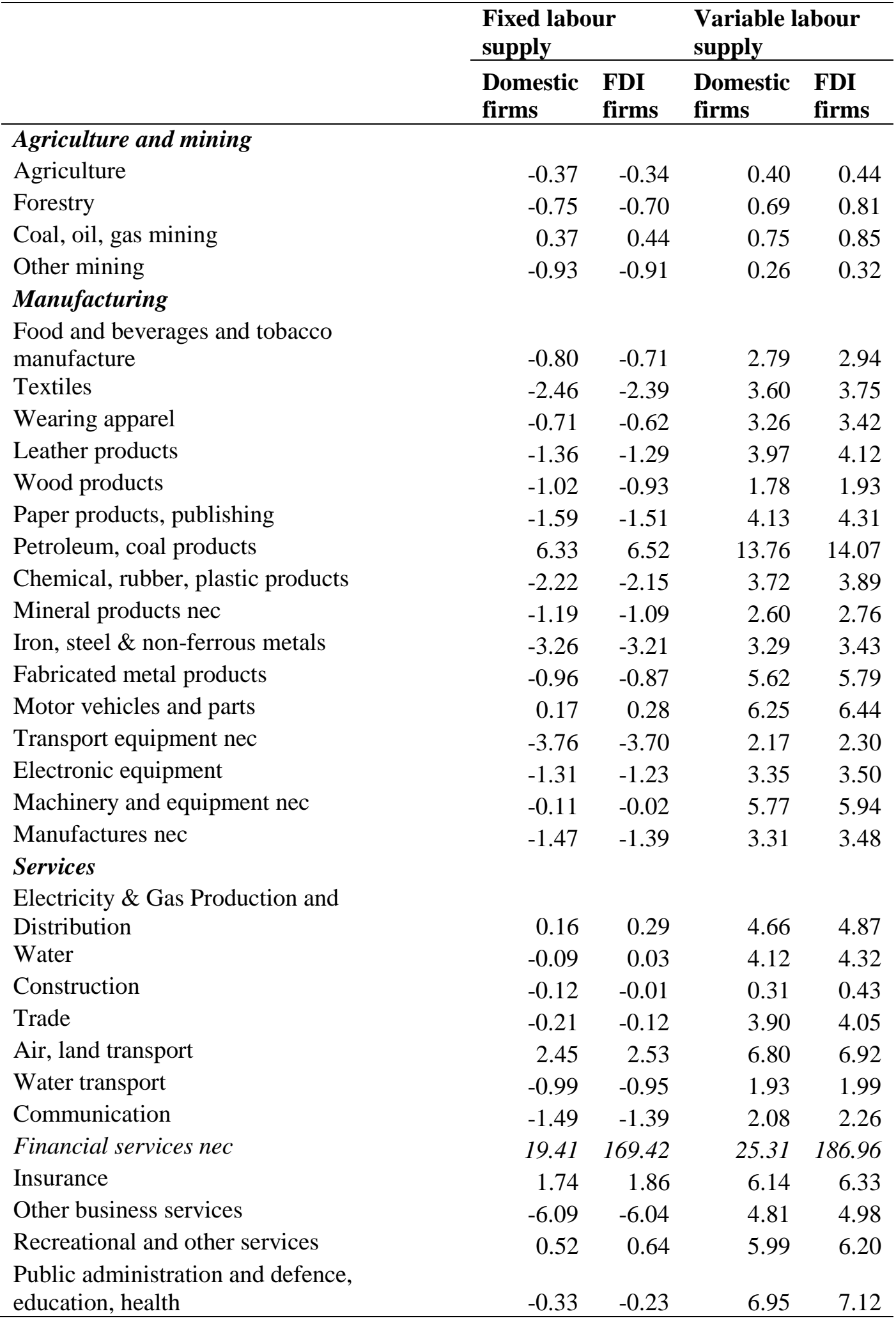

Source: Author's projection from GTAP 7 Database and FTAP-VN 


\begin{tabular}{|c|c|c|c|c|c|c|}
\hline & \multicolumn{2}{|c|}{ Fixed labour supply } & \multicolumn{4}{|c|}{ Variable labour supply } \\
\hline & $\begin{array}{l}\text { Domestic } \\
\text { firms }\end{array}$ & FDI firms & $\begin{array}{l}\text { Change in } \\
\text { the relative } \\
\text { price of } \\
\text { domestic to } \\
\text { FDI } \\
\text { product (\%) }\end{array}$ & $\begin{array}{l}\text { Domestic } \\
\text { firms }\end{array}$ & FDI firms & $\begin{array}{l}\text { Change in } \\
\text { the relative } \\
\text { price of } \\
\text { domestic to } \\
\text { FDI } \\
\text { product (\%) }\end{array}$ \\
\hline \multicolumn{7}{|l|}{ Agriculture and mining } \\
\hline Agriculture & 0.20 & 0.20 & 0.002 & 0.81 & 0.80 & 0.005 \\
\hline Forestry & 0.00 & 0.00 & 0.005 & 0.54 & 0.52 & 0.012 \\
\hline Coal, oil, gas mining & -0.05 & -0.05 & 0.007 & -0.02 & -0.03 & 0.010 \\
\hline Other mining & 0.08 & 0.07 & 0.003 & 0.09 & 0.09 & 0.007 \\
\hline \multicolumn{7}{|l|}{ Manufacturing } \\
\hline Food and beverages and tobacco manufacture & 0.31 & 0.30 & 0.009 & -0.03 & -0.05 & 0.015 \\
\hline Textiles & 0.30 & 0.30 & 0.007 & -0.15 & -0.17 & 0.016 \\
\hline Wearing apparel & 0.14 & 0.13 & 0.009 & -0.26 & -0.27 & 0.016 \\
\hline Leather products & 0.15 & 0.15 & 0.008 & -0.37 & -0.39 & 0.015 \\
\hline Wood products & 0.13 & 0.12 & 0.010 & -0.15 & -0.17 & 0.016 \\
\hline Paper products, publishing & 0.56 & 0.55 & 0.009 & 0.10 & 0.09 & 0.017 \\
\hline Petroleum, coal products & -0.58 & -0.60 & 0.017 & -0.88 & -0.90 & 0.027 \\
\hline Chemical, rubber, plastic products & 0.35 & 0.34 & 0.008 & -0.14 & -0.16 & 0.016 \\
\hline Mineral products nec & 0.37 & 0.36 & 0.010 & -0.22 & -0.23 & 0.016 \\
\hline Iron, steel \& non-ferrous metals & 0.40 & 0.40 & 0.006 & -0.19 & -0.21 & 0.014 \\
\hline Fabricated metal products & 0.13 & 0.12 & 0.009 & -0.55 & -0.57 & 0.017 \\
\hline Motor vehicles and parts & 0.16 & 0.15 & 0.010 & -0.38 & -0.40 & 0.018 \\
\hline Transport equipment nec & 0.63 & 0.63 & 0.007 & -0.29 & -0.30 & 0.014 \\
\hline Electronic equipment & 0.21 & 0.21 & 0.008 & -0.30 & -0.31 & 0.015 \\
\hline Machinery and equipment nec & 0.02 & 0.01 & 0.009 & -0.57 & -0.59 & 0.016 \\
\hline Manufactures nec & 0.21 & 0.20 & 0.009 & -0.15 & -0.17 & 0.017 \\
\hline
\end{tabular}




\begin{tabular}{|c|c|c|c|c|c|c|}
\hline & \multicolumn{2}{|c|}{ Fixed labour supply } & \multicolumn{4}{|c|}{ Variable labour supply } \\
\hline & $\begin{array}{l}\text { Domestic } \\
\text { firms }\end{array}$ & FDI firms & $\begin{array}{l}\text { Change in } \\
\text { the relative } \\
\text { price of } \\
\text { domestic to } \\
\text { FDI } \\
\text { product (\%) }\end{array}$ & $\begin{array}{l}\text { Domestic } \\
\text { firms }\end{array}$ & FDI firms & $\begin{array}{l}\text { Change in } \\
\text { the relative } \\
\text { price of } \\
\text { domestic to } \\
\text { FDI } \\
\text { product }(\%)\end{array}$ \\
\hline Electricity \& Gas Production and Distribution & 1.91 & 1.90 & 0.013 & 1.53 & 1.51 & 0.021 \\
\hline Water & 1.56 & 1.55 & 0.012 & 0.86 & 0.84 & 0.019 \\
\hline Construction & 0.44 & 0.43 & 0.011 & -0.59 & -0.60 & 0.012 \\
\hline Trade & -0.69 & -0.70 & 0.010 & -1.42 & -1.44 & 0.014 \\
\hline Air, land transport & -0.75 & -0.76 & 0.009 & -1.21 & -1.22 & 0.013 \\
\hline Water transport & 0.26 & 0.25 & 0.006 & -0.08 & -0.09 & 0.008 \\
\hline Communication & 0.59 & 0.58 & 0.010 & 0.21 & 0.19 & 0.018 \\
\hline Financial services nec & -16.93 & -23.42 & 6.493 & -17.82 & -24.36 & 6.535 \\
\hline Insurance & -0.12 & -0.14 & 0.012 & -0.43 & -0.45 & 0.018 \\
\hline Other business services & 1.22 & 1.21 & 0.005 & -0.16 & -0.18 & 0.017 \\
\hline Recreational and other services & 0.46 & 0.45 & 0.012 & -0.24 & -0.26 & 0.020 \\
\hline Public administration and defence, education, health & 1.18 & 1.17 & 0.010 & -0.93 & -0.94 & 0.016 \\
\hline
\end{tabular}

Source: Author's projection from GTAP 7 Database and FTAP-VN 
Table 7. Projected change in the prices of labour and capital (\%)

\begin{tabular}{|c|c|c|c|c|c|c|c|c|c|c|c|c|}
\hline & \multicolumn{6}{|c|}{ Fixed labour supply } & \multicolumn{6}{|c|}{ Variable labour supply } \\
\hline & \multicolumn{3}{|c|}{ Domestic firms } & \multicolumn{3}{|c|}{ FDI firms } & \multicolumn{3}{|c|}{ Domestic firms } & \multicolumn{3}{|c|}{ FDI firms } \\
\hline & $\begin{array}{l}\text { UnSkL } \\
\text { ab }\end{array}$ & $\begin{array}{l}\text { SkLa } \\
\text { b }\end{array}$ & $\begin{array}{l}\text { Capit } \\
\text { al }\end{array}$ & $\begin{array}{l}\text { UnSkL } \\
\text { ab }\end{array}$ & $\begin{array}{l}\text { SkLa } \\
\text { b }\end{array}$ & $\begin{array}{l}\text { Capit } \\
\text { al }\end{array}$ & $\begin{array}{l}\text { UnSkL } \\
\text { ab }\end{array}$ & $\begin{array}{l}\text { SkLa } \\
\text { b }\end{array}$ & $\begin{array}{l}\text { Capit } \\
\text { al }\end{array}$ & $\begin{array}{l}\text { UnSkL } \\
\text { ab }\end{array}$ & $\begin{array}{l}\text { SkLa } \\
\text { b }\end{array}$ & $\begin{array}{l}\text { Capit } \\
\text { al }\end{array}$ \\
\hline \multicolumn{13}{|l|}{ Agriculture and mining } \\
\hline Agriculture & 2.35 & 3.74 & -0.31 & 2.35 & 3.74 & -0.49 & -0.60 & -0.60 & 2.18 & -0.60 & -0.60 & 1.84 \\
\hline Forestry & 2.35 & 3.74 & -1.49 & 2.35 & 3.74 & -1.58 & -0.60 & -0.60 & 2.92 & -0.60 & -0.60 & 2.73 \\
\hline Coal, oil, gas mining & 2.35 & 3.74 & 4.22 & 2.35 & 3.74 & 3.97 & -0.60 & -0.60 & 5.44 & -0.60 & -0.60 & 5.07 \\
\hline Other mining & 2.35 & 3.74 & -2.42 & 2.35 & 3.74 & -2.53 & -0.60 & -0.60 & 1.16 & -0.60 & -0.60 & 0.88 \\
\hline \multicolumn{13}{|l|}{ Manufacturing } \\
\hline $\begin{array}{l}\text { Food and beverages and tobacco } \\
\text { manufacture }\end{array}$ & 2.35 & 3.74 & 1.27 & 2.35 & 3.74 & 1.24 & -0.60 & -0.60 & 3.09 & -0.60 & -0.60 & 3.03 \\
\hline Textiles & 2.35 & 3.74 & -0.71 & 2.35 & 3.74 & -0.73 & -0.60 & -0.60 & 3.85 & -0.60 & -0.60 & 3.79 \\
\hline Wearing apparel & 2.35 & 3.74 & 1.20 & 2.35 & 3.74 & 1.16 & -0.60 & -0.60 & 4.25 & -0.60 & -0.60 & 4.18 \\
\hline Leather products & 2.35 & 3.74 & 0.58 & 2.35 & 3.74 & 0.55 & -0.60 & -0.60 & 4.42 & -0.60 & -0.60 & 4.35 \\
\hline Wood products & 2.35 & 3.74 & 0.78 & 2.35 & 3.74 & 0.74 & -0.60 & -0.60 & 2.09 & -0.60 & -0.60 & 2.04 \\
\hline Paper products, publishing & 2.35 & 3.74 & 0.33 & 2.35 & 3.74 & 0.31 & -0.60 & -0.60 & 4.53 & -0.60 & -0.60 & 4.48 \\
\hline Petroleum, coal products & 2.35 & 3.74 & 10.42 & 2.35 & 3.74 & 10.38 & -0.60 & -0.60 & 16.53 & -0.60 & -0.60 & 16.48 \\
\hline Chemical, rubber, plastic products & 2.35 & 3.74 & -0.30 & 2.35 & 3.74 & -0.33 & -0.60 & -0.60 & 3.85 & -0.60 & -0.60 & 3.80 \\
\hline Mineral products nec & 2.35 & 3.74 & 0.73 & 2.35 & 3.74 & 0.70 & -0.60 & -0.60 & 2.88 & -0.60 & -0.60 & 2.85 \\
\hline Iron, steel \& non-ferrous metals & 2.35 & 3.74 & -1.54 & 2.35 & 3.74 & -1.57 & -0.60 & -0.60 & 3.37 & -0.60 & -0.60 & 3.30 \\
\hline Fabricated metal products & 2.35 & 3.74 & 1.28 & 2.35 & 3.74 & 1.24 & -0.60 & -0.60 & 5.53 & -0.60 & -0.60 & 5.47 \\
\hline Motor vehicles and parts & 2.35 & 3.74 & 2.51 & 2.35 & 3.74 & 2.48 & -0.60 & -0.60 & 6.79 & -0.60 & -0.60 & 6.73 \\
\hline Transport equipment nec & 2.35 & 3.74 & -1.39 & 2.35 & 3.74 & -1.40 & -0.60 & -0.60 & 1.64 & -0.60 & -0.60 & 1.60 \\
\hline Electronic equipment & 2.35 & 3.74 & 0.69 & 2.35 & 3.74 & 0.66 & -0.60 & -0.60 & 3.65 & -0.60 & -0.60 & 3.59 \\
\hline Machinery and equipment nec & 2.35 & 3.74 & 2.23 & 2.35 & 3.74 & 2.18 & -0.60 & -0.60 & 5.96 & -0.60 & -0.60 & 5.89 \\
\hline Manufactures nec & 2.35 & 3.74 & 0.21 & 2.35 & 3.74 & 0.19 & -0.60 & -0.60 & 4.00 & -0.60 & -0.60 & 3.95 \\
\hline
\end{tabular}




\begin{tabular}{|c|c|c|c|c|c|c|c|c|c|c|c|c|}
\hline & \multicolumn{6}{|c|}{ Fixed labour supply } & \multicolumn{6}{|c|}{ Variable labour supply } \\
\hline & \multicolumn{3}{|c|}{ Domestic firms } & \multicolumn{3}{|c|}{ FDI firms } & \multicolumn{3}{|c|}{ Domestic firms } & \multicolumn{3}{|c|}{ FDI firms } \\
\hline & $\begin{array}{l}\text { UnSkL } \\
\text { ab }\end{array}$ & $\begin{array}{l}\text { SkLa } \\
\text { b }\end{array}$ & $\begin{array}{l}\text { Capit } \\
\text { al }\end{array}$ & $\begin{array}{l}\text { UnSkL } \\
\text { ab }\end{array}$ & $\begin{array}{l}\text { SkLa } \\
\text { b }\end{array}$ & $\begin{array}{l}\text { Capit } \\
\text { al }\end{array}$ & $\begin{array}{l}\text { UnSkL } \\
\text { ab }\end{array}$ & $\begin{array}{l}\text { SkLa } \\
\text { b }\end{array}$ & $\begin{array}{l}\text { Capit } \\
\text { al }\end{array}$ & $\begin{array}{l}\text { UnSkL } \\
\text { ab }\end{array}$ & $\begin{array}{l}\text { SkLa } \\
\text { b }\end{array}$ & $\begin{array}{l}\text { Capit } \\
\text { al }\end{array}$ \\
\hline $\begin{array}{l}\text { Electricity \& Gas Production and } \\
\text { Distribution }\end{array}$ & 2.35 & 3.74 & 2.71 & 2.35 & 3.74 & 2.69 & -0.60 & -0.60 & 5.74 & -0.60 & -0.60 & 5.72 \\
\hline Water & 2.35 & 3.74 & 2.39 & 2.35 & 3.74 & 2.37 & -0.60 & -0.60 & 4.70 & -0.60 & -0.60 & 4.68 \\
\hline Construction & 2.35 & 3.74 & 2.18 & 2.35 & 3.74 & 2.15 & -0.60 & -0.60 & -0.08 & -0.60 & -0.60 & -0.11 \\
\hline Trade & 2.35 & 3.74 & 2.20 & 2.35 & 3.74 & 2.17 & -0.60 & -0.60 & 3.12 & -0.60 & -0.60 & 3.08 \\
\hline Air, land transport & 2.35 & 3.74 & 4.92 & 2.35 & 3.74 & 4.83 & -0.60 & -0.60 & 6.30 & -0.60 & -0.60 & 6.18 \\
\hline Water transport & 2.35 & 3.74 & 1.38 & 2.35 & 3.74 & 1.30 & -0.60 & -0.60 & 1.45 & -0.60 & -0.60 & 1.34 \\
\hline Communication & 2.35 & 3.74 & 0.32 & 2.35 & 3.74 & 0.32 & -0.60 & -0.60 & 2.63 & -0.60 & -0.60 & 2.61 \\
\hline Financial services nec & 2.35 & 3.74 & 7.29 & 2.35 & 3.74 & 95.87 & -0.60 & -0.60 & 9.60 & -0.60 & -0.60 & 100.9 \\
\hline Insurance & 2.35 & 3.74 & 5.47 & 2.35 & 3.74 & 5.43 & -0.60 & -0.60 & 9.00 & -0.60 & -0.60 & 8.95 \\
\hline Other business services & 2.35 & 3.74 & -2.82 & 2.35 & 3.74 & -2.83 & -0.60 & -0.60 & 3.69 & -0.60 & -0.60 & 3.65 \\
\hline Recreational and other services & 2.35 & 3.74 & 3.24 & 2.35 & 3.74 & 3.22 & -0.60 & -0.60 & 6.46 & -0.60 & -0.60 & 6.43 \\
\hline $\begin{array}{l}\text { Public administration and defence, } \\
\text { education, health }\end{array}$ & 2.35 & 3.74 & 2.66 & 2.35 & 3.74 & 2.63 & -0.60 & -0.60 & 5.16 & -0.60 & -0.60 & 5.11 \\
\hline
\end{tabular}


Table 8. Projected change in the relative price of labour to capital

\begin{tabular}{|c|c|c|c|c|c|c|c|c|}
\hline & \multicolumn{4}{|c|}{ Fixed labour supply } & \multicolumn{4}{|c|}{ Variable labour supply } \\
\hline & \multicolumn{2}{|c|}{ Domestic firms } & \multicolumn{2}{|l|}{ FDI firms } & \multicolumn{2}{|c|}{ Domestic firms } & \multirow{2}{*}{$\begin{array}{l}\text { FDI firms } \\
\text { UnSkLab }\end{array}$} & \multirow[b]{2}{*}{ SkLab } \\
\hline & UnSkLab & SkLab & UnSkLab & SkLab & UnSkLab & SkLab & & \\
\hline \multicolumn{9}{|l|}{ Agriculture and mining } \\
\hline Agriculture & 2.67 & 4.06 & 2.85 & 4.23 & -2.78 & -2.78 & -2.44 & -2.44 \\
\hline Forestry & 3.85 & 5.24 & 3.93 & 5.32 & -3.52 & -3.52 & -3.33 & -3.33 \\
\hline Coal, oil, gas mining & -1.87 & -0.48 & -1.61 & -0.22 & -6.04 & -6.04 & -5.68 & -5.68 \\
\hline Other mining & 4.78 & 6.17 & 4.89 & 6.28 & -1.76 & -1.76 & -1.49 & -1.49 \\
\hline \multicolumn{9}{|l|}{ Manufacturing } \\
\hline $\begin{array}{l}\text { Food and beverages and tobacco } \\
\text { manufacture }\end{array}$ & 1.08 & 2.47 & 1.12 & 2.51 & -3.69 & -3.69 & -3.64 & -3.64 \\
\hline Textiles & 3.06 & 4.45 & 3.09 & 4.48 & -4.45 & -4.45 & -4.40 & -4.40 \\
\hline Wearing apparel & 1.15 & 2.54 & 1.19 & 2.58 & -4.85 & -4.85 & -4.78 & -4.78 \\
\hline Leather products & 1.77 & 3.16 & 1.81 & 3.20 & -5.03 & -5.03 & -4.95 & -4.95 \\
\hline Wood products & 1.58 & 2.97 & 1.61 & 3.00 & -2.69 & -2.69 & -2.64 & -2.64 \\
\hline Paper products, publishing & 2.02 & 3.41 & 2.05 & 3.44 & -5.13 & -5.13 & -5.08 & -5.08 \\
\hline Petroleum, coal products & -8.06 & -6.67 & -8.03 & -6.64 & -17.13 & -17.13 & -17.08 & -17.08 \\
\hline Chemical, rubber, plastic products & 2.66 & 4.05 & 2.68 & 4.07 & -4.46 & -4.46 & -4.41 & -4.41 \\
\hline Mineral products nec & 1.63 & 3.02 & 1.65 & 3.04 & -3.49 & -3.49 & -3.45 & -3.45 \\
\hline Iron, steel \& non-ferrous metals & 3.90 & 5.29 & 3.93 & 5.32 & -3.97 & -3.97 & -3.90 & -3.90 \\
\hline Fabricated metal products & 1.08 & 2.47 & 1.11 & 2.50 & -6.13 & -6.13 & -6.07 & -6.07 \\
\hline Motor vehicles and parts & -0.16 & 1.23 & -0.13 & 1.26 & -7.39 & -7.39 & -7.34 & -7.34 \\
\hline Transport equipment nec & 3.74 & 5.13 & 3.76 & 5.15 & -2.24 & -2.24 & -2.20 & -2.20 \\
\hline Electronic equipment & 1.66 & 3.05 & 1.70 & 3.08 & -4.25 & -4.25 & -4.19 & -4.19 \\
\hline Machinery and equipment nec & 0.13 & 1.52 & 0.17 & 1.56 & -6.57 & -6.57 & -6.49 & -6.49 \\
\hline Manufactures nec & 2.14 & 3.53 & 2.17 & 3.56 & -4.61 & -4.61 & -4.56 & -4.56 \\
\hline \multicolumn{9}{|l|}{ Services } \\
\hline $\begin{array}{l}\text { Electricity \& Gas Production and } \\
\text { Distribution }\end{array}$ & -0.35 & 1.04 & -0.34 & 1.05 & -6.35 & -6.35 & -6.32 & -6.32 \\
\hline Water & -0.03 & 1.36 & -0.02 & 1.37 & -5.30 & -5.30 & -5.28 & -5.28 \\
\hline
\end{tabular}




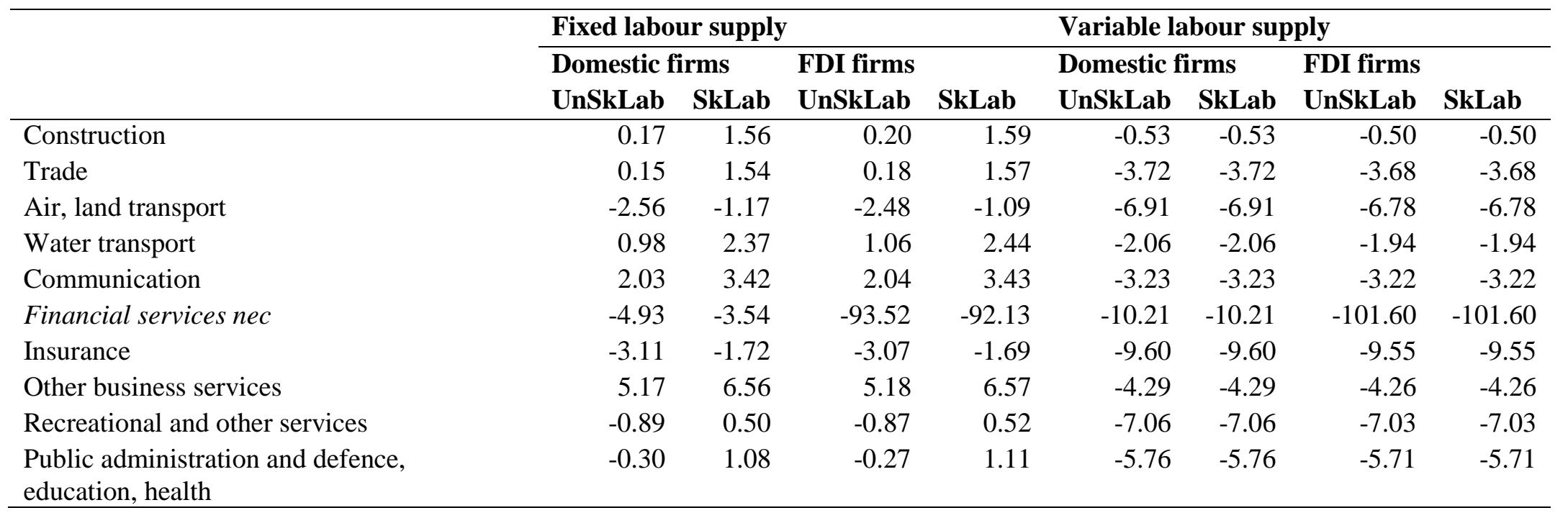

Source: Author's projection from GTAP 7 Database and FTAP-VN 
Table 9. Projected employment growth by industry (\%)

\begin{tabular}{|c|c|c|c|c|c|c|c|c|c|c|}
\hline & \multicolumn{5}{|c|}{ Fixed labour supply } & \multicolumn{5}{|c|}{ Variable labour supply } \\
\hline & \multicolumn{2}{|c|}{ Domestic firms } & \multicolumn{2}{|l|}{ FDI firms } & \multirow[t]{2}{*}{ All } & \multicolumn{2}{|c|}{ Domestic firms } & \multirow{2}{*}{$\begin{array}{l}\text { FDI firms } \\
\text { UnSkLab }\end{array}$} & \multirow[b]{2}{*}{ SkLab } & \multirow[t]{2}{*}{ All } \\
\hline & UnSkLab & SkLab & UnSkLab & SkLab & & UnSkLab & SkLab & & & \\
\hline \multicolumn{11}{|l|}{ Agriculture and mining } \\
\hline Agriculture & -0.78 & -1.08 & -0.76 & -1.06 & -0.78 & 0.85 & 0.85 & 0.90 & 0.90 & 0.85 \\
\hline Forestry & -1.12 & -1.38 & -1.07 & -1.34 & -1.12 & 1.04 & 1.04 & 1.16 & 1.16 & 1.05 \\
\hline Coal, oil, gas mining & 0.76 & 0.49 & 0.82 & 0.55 & 0.73 & 1.79 & 1.79 & 1.88 & 1.88 & 1.81 \\
\hline Other mining & -1.45 & -1.72 & -1.43 & -1.69 & -1.48 & 0.44 & 0.44 & 0.50 & 0.50 & 0.45 \\
\hline \multicolumn{11}{|l|}{ Manufacturing } \\
\hline Food and beverages and tobacco manufacture & -1.15 & -2.63 & -1.09 & -2.57 & -1.36 & 4.52 & 4.52 & 4.63 & 4.63 & 4.55 \\
\hline Textiles & -3.98 & -5.60 & -3.94 & -5.55 & -4.19 & 6.15 & 6.15 & 6.27 & 6.27 & 6.20 \\
\hline Wearing apparel & -1.40 & -3.06 & -1.35 & -3.01 & -1.58 & 6.69 & 6.69 & 6.79 & 6.79 & 6.72 \\
\hline Leather products & -2.24 & -3.88 & -2.19 & -3.83 & -2.45 & 6.94 & 6.94 & 7.04 & 7.04 & 6.97 \\
\hline Wood products & -1.97 & -3.62 & -1.91 & -3.56 & -2.15 & 3.63 & 3.63 & 3.73 & 3.73 & 3.64 \\
\hline Paper products, publishing & -2.57 & -4.21 & -2.51 & -4.15 & -2.81 & 7.14 & 7.14 & 7.27 & 7.27 & 7.16 \\
\hline Petroleum, coal products & 11.06 & 9.19 & 11.22 & 9.35 & 10.78 & 24.16 & 24.16 & 24.44 & 24.44 & 24.22 \\
\hline Chemical, rubber, plastic products & -3.44 & -5.06 & -3.38 & -5.01 & -3.68 & 6.16 & 6.16 & 6.29 & 6.29 & 6.22 \\
\hline Mineral products nec & -2.04 & -3.69 & -1.97 & -3.62 & -2.26 & 4.78 & 4.78 & 4.90 & 4.90 & 4.81 \\
\hline Iron, steel \& non-ferrous metals & -5.11 & -6.71 & -5.08 & -6.68 & -5.35 & 5.47 & 5.47 & 5.56 & 5.56 & 5.50 \\
\hline Fabricated metal products & -1.30 & -2.96 & -1.23 & -2.89 & -1.52 & 8.53 & 8.53 & 8.67 & 8.67 & 8.58 \\
\hline Motor vehicles and parts & 0.38 & -1.31 & 0.46 & -1.23 & 0.18 & 10.33 & 10.33 & 10.49 & 10.49 & 10.44 \\
\hline Transport equipment nec & -4.91 & -6.51 & -4.86 & -6.46 & -5.12 & 3.01 & 3.01 & 3.12 & 3.12 & 3.08 \\
\hline Electronic equipment & -2.09 & -3.73 & -2.03 & -3.68 & -2.35 & 5.85 & 5.85 & 5.95 & 5.95 & 5.88 \\
\hline Machinery and equipment nec & -0.01 & -1.69 & 0.05 & -1.63 & -0.26 & 9.13 & 9.13 & 9.25 & 9.25 & 9.19 \\
\hline Manufactures nec & -2.74 & -4.37 & -2.68 & -4.31 & -2.88 & 6.37 & 6.37 & 6.50 & 6.50 & 6.43 \\
\hline \multicolumn{11}{|l|}{ Services } \\
\hline Electricity \& Gas Production and Distribution & 0.65 & -1.04 & 0.76 & -0.94 & 0.07 & 8.84 & 8.84 & 9.03 & 9.03 & 8.85 \\
\hline Water & 0.22 & -1.47 & 0.33 & -1.36 & -0.35 & 7.35 & 7.35 & 7.53 & 7.53 & 7.36 \\
\hline Construction & -0.08 & -1.95 & 0.00 & -1.86 & -0.36 & 0.64 & 0.64 & 0.74 & 0.74 & 0.65 \\
\hline Trade & -0.10 & -2.34 & -0.04 & -2.27 & -0.47 & 6.71 & 6.71 & 6.82 & 6.82 & 6.78 \\
\hline
\end{tabular}




\begin{tabular}{|c|c|c|c|c|c|c|c|c|c|c|}
\hline & \multicolumn{5}{|c|}{ Fixed labour supply } & \multicolumn{5}{|c|}{ Variable labour supply } \\
\hline & \multicolumn{2}{|c|}{ Domestic firms } & \multicolumn{2}{|l|}{ FDI firms } & \multirow[t]{2}{*}{ All } & \multicolumn{2}{|c|}{ Domestic firms } & \multicolumn{2}{|l|}{ FDI firms } & \multirow[t]{2}{*}{ All } \\
\hline & UnSkLab & SkLab & UnSkLab & SkLab & & UnSkLab & SkLab & UnSkLab & SkLab & \\
\hline Air, land transport & 4.73 & 2.38 & 4.72 & 2.38 & 4.30 & 12.71 & 12.71 & 12.71 & 12.71 & 12.71 \\
\hline Water transport & -1.55 & -3.75 & -1.58 & -3.78 & -1.96 & 3.62 & 3.62 & 3.57 & 3.57 & 3.61 \\
\hline Communication & -2.58 & -4.22 & -2.50 & -4.14 & -3.25 & 4.40 & 4.40 & 4.56 & 4.56 & 4.40 \\
\hline Financial services nec & 7.58 & 5.77 & 178.10 & 173.41 & 22.08 & 15.37 & 15.37 & 202.28 & 202.28 & 32.20 \\
\hline Insurance & 4.16 & 2.40 & 4.25 & 2.49 & 3.48 & 12.99 & 12.99 & 13.15 & 13.15 & 13.06 \\
\hline Other business services & -6.84 & -8.41 & -6.80 & -8.37 & -7.46 & 5.96 & 5.96 & 6.11 & 6.11 & 6.03 \\
\hline Recreational and other services & 1.37 & -0.34 & 1.47 & -0.24 & 0.67 & 9.83 & 9.83 & 10.01 & 10.01 & 9.83 \\
\hline $\begin{array}{l}\text { Public administration and defence, education, } \\
\text { health }\end{array}$ & 0.59 & -1.11 & 0.67 & -1.02 & -0.44 & 8.00 & 8.00 & 8.15 & 8.15 & 8.00 \\
\hline
\end{tabular}

Source: Author's projection from GTAP 7 Database and FTAP-VN 
Table 10. Change in the employment structure

\begin{tabular}{|c|c|c|c|c|}
\hline & \multirow{3}{*}{$\begin{array}{l}\begin{array}{l}\text { Fixed } \\
\text { labour } \\
\text { supply }\end{array} \\
\begin{array}{l}\text { Share } \\
\text { change (\%) }\end{array}\end{array}$} & \multicolumn{3}{|c|}{ Variable labour supply } \\
\hline & & \multirow{2}{*}{$\begin{array}{l}\text { Share } \\
\text { change } \\
(\%)\end{array}$} & \multicolumn{2}{|c|}{$\begin{array}{l}\text { Employment } \\
\text { increase }\end{array}$} \\
\hline & & & $(' 000)$ & $\%$ \\
\hline Agriculture and mining & -0.08 & -1.01 & 40.46 & 3.72 \\
\hline Agriculture & -0.10 & -0.68 & 19.41 & 1.79 \\
\hline Forestry & -0.01 & -0.06 & 2.34 & 0.22 \\
\hline Coal, oil, gas mining & 0.04 & -0.25 & 18.52 & 1.70 \\
\hline Other mining & 0.00 & -0.01 & 0.20 & 0.02 \\
\hline Manufacturing & -0.81 & 0.00 & 393.67 & 36.23 \\
\hline Food and beverages and tobacco manufacture & -0.10 & -0.12 & 55.55 & 5.11 \\
\hline Textiles & -0.12 & 0.00 & 29.85 & 2.75 \\
\hline Wearing apparel & -0.03 & 0.01 & 23.91 & 2.20 \\
\hline Leather products & -0.10 & 0.02 & 46.72 & 4.30 \\
\hline Wood products & -0.03 & -0.03 & 7.89 & 0.73 \\
\hline Paper products, publishing & -0.03 & 0.01 & 11.53 & 1.06 \\
\hline Petroleum, coal products & 0.06 & 0.09 & 21.86 & 2.01 \\
\hline Chemical, rubber, plastic products & -0.16 & 0.00 & 47.61 & 4.38 \\
\hline Mineral products nec & -0.06 & -0.03 & 20.40 & 1.88 \\
\hline Iron, steel \& non-ferrous metals & -0.05 & -0.01 & 8.89 & 0.82 \\
\hline Fabricated metal products & -0.01 & 0.01 & 10.19 & 0.94 \\
\hline Motor vehicles and parts & 0.00 & 0.08 & 38.51 & 3.54 \\
\hline Transport equipment nec & -0.12 & -0.07 & 12.06 & 1.11 \\
\hline Electronic equipment & -0.04 & -0.01 & 19.11 & 1.76 \\
\hline Machinery and equipment nec & 0.00 & 0.05 & 29.77 & 2.74 \\
\hline Manufactures nec & -0.03 & 0.00 & 9.82 & 0.90 \\
\hline Services & 0.36 & 1.00 & 652.57 & 60.05 \\
\hline Electricity \& Gas Production and Distribution & 0.01 & 0.17 & 109.50 & 10.08 \\
\hline Water & 0.00 & 0.00 & 3.08 & 0.28 \\
\hline Construction & -0.03 & -0.37 & 7.69 & 0.71 \\
\hline Trade & -0.01 & 0.01 & 15.54 & 1.43 \\
\hline Air, land transport & 0.02 & 0.03 & 10.88 & 1.00 \\
\hline Water transport & 0.00 & 0.00 & 0.96 & 0.09 \\
\hline Communication & -0.04 & -0.02 & 9.49 & 0.87 \\
\hline Financial services nec & 0.78 & 0.86 & 196.64 & 18.09 \\
\hline Insurance & 0.01 & 0.02 & 5.90 & 0.54 \\
\hline Other business services & -0.34 & -0.01 & 46.98 & 4.32 \\
\hline Recreational and other services & 0.02 & 0.08 & 42.49 & 3.91 \\
\hline Public administration and defence, education, health & -0.06 & 0.23 & 203.43 & 18.72 \\
\hline
\end{tabular}

Source: Author's projection from GTAP 7 Database and FTAP-VN 


\section{Appendix}

Table A1. List of aggregated sectors for simulation

\begin{tabular}{|c|c|c|}
\hline ID & Sector & Descriptions \\
\hline 1 & Agriculture & $\begin{array}{l}\text { Paddy Rice: rice, husked and un-husked. Wheat: wheat and meslin. Other } \\
\text { Grains: maize (corn), barley, rye, oats, other cereals, cassava, truffles. Oil } \\
\text { Seeds: oil seeds and oleaginous fruit; soy beans, copra. Cane \& Beet: sugar } \\
\text { cane and sugar beet. Plant Fibers: cotton, flax, hemp, sisal and other raw } \\
\text { vegetable materials used in textiles. Other Crops: live plants; cut flowers } \\
\text { and flower buds; flower seeds and fruit seeds; vegetable seeds, beverage } \\
\text { and spice crops, unmanufactured tobacco, cereal straw and husks, } \\
\text { unprepared, whether or not chopped, ground, pressed or in the form of } \\
\text { pellets; Swedes, mangolds, fodder roots, hay, lucerne (alfalfa), clover, } \\
\text { sainfoin, forage kale, lupines, vetches and similar forage products, } \\
\text { whether or not in the form of pellets, plants and parts of plants used } \\
\text { primarily in perfumery, in pharmacy, or for insecticidal, fungicidal or } \\
\text { similar purposes, sugar beet seed and seeds of forage plants, other raw } \\
\text { vegetable materials. Cattle: cattle, sheep, goats, horses, asses, mules, and } \\
\text { hinnies; and semen thereof. Other Animal Products: swine, poultry and } \\
\text { other live animals; eggs, in shell (fresh or cooked), natural honey, snails } \\
\text { (fresh or preserved) except sea snails; frogs' legs, edible products of animal } \\
\text { origin n.e.c., hides, skins and fur skins, raw, insect waxes and spermaceti, } \\
\text { whether or not refined or coloured. Raw milk. Wool: wool, silk, and other } \\
\text { raw animal materials used in textile. Fishing: hunting, trapping and game } \\
\text { propagation including related service activities, fishing, fish farms; service } \\
\text { activities incidental to fishing }\end{array}$ \\
\hline 2 & Forestry & Forestry: forestry, logging and related service activities. \\
\hline 3 & $\begin{array}{l}\text { Coal, oil, gas } \\
\text { mining }\end{array}$ & $\begin{array}{l}\text { Coal: mining and agglomeration of hard coal, lignite and peat. Oil: } \\
\text { extraction of crude petroleum and natural gas (part), service activities } \\
\text { incidental to oil and gas extraction excluding surveying (part). Gas: } \\
\text { extraction of crude petroleum and natural gas (part), service activities } \\
\text { incidental to oil and gas extraction excluding surveying (part) }\end{array}$ \\
\hline 4 & Other mining & $\begin{array}{l}\text { Other Mining: mining of metal ores, uranium, gems. other mining and } \\
\text { quarrying }\end{array}$ \\
\hline 5 & $\begin{array}{ll}\text { Food and } \\
\text { beverages and } \\
\text { tobacco } \\
\text { manufacture }\end{array}$ & $\begin{array}{l}\text { Cattle Meat: fresh or chilled meat and edible offal of cattle, sheep, goats, } \\
\text { horses, asses, mules, and hinnies. Raw fats or grease from any animal or } \\
\text { bird. Other Meat: pig meat and offal. Preserves and preparations of meat, } \\
\text { meat offal or blood, flours, meals and pellets of meat or inedible meat } \\
\text { offal; greaves. Vegetable Oils: crude and refined oils of soya-bean, maize } \\
\text { (corn),olive, sesame, ground-nut, olive, sunflower-seed, safflower, cotton- } \\
\text { seed, rape, colza and canola, mustard, coconut palm, palm kernel, castor, } \\
\text { tung jojoba, babassu and linseed, perhaps partly or wholly hydrogenated, } \\
\text { inter-esterified, re-esterified or elaidinised. Also margarine and similar } \\
\text { preparations, animal or vegetable waxes, fats and oils and their fractions, } \\
\text { cotton linters, oil-cake and other solid residues resulting from the } \\
\text { extraction of vegetable fats or oils; flours and meals of oil seeds or } \\
\text { oleaginous fruits, except those of mustard; degras and other residues }\end{array}$ \\
\hline
\end{tabular}




\begin{tabular}{|c|c|c|}
\hline ID & Sector & Descriptions \\
\hline & & $\begin{array}{l}\text { resulting from the treatment of fatty substances or animal or vegetable } \\
\text { waxes. Milk: dairy products. Processed Rice: rice, semi- or wholly milled. } \\
\text { Sugar Other Food: prepared and preserved fish or vegetables, fruit juices } \\
\text { and vegetable juices, prepared and preserved fruit and nuts, all cereal } \\
\text { flours, groats, meal and pellets of wheat, cereal groats, meal and pellets } \\
\text { n.e.c., other cereal grain products (including corn flakes), other vegetable } \\
\text { flours and meals, mixes and doughs for the preparation of bakers' wares, } \\
\text { starches and starch products; sugars and sugar syrups n.e.c., preparations } \\
\text { used in animal feeding, bakery products, cocoa, chocolate and sugar } \\
\text { confectionery, macaroni, noodles, couscous and similar farinaceous } \\
\text { products, food products n.e.c. Beverages and Tobacco products. }\end{array}$ \\
\hline 6 & Textiles & Textiles: textiles and man-made fibers \\
\hline 7 & $\begin{array}{l}\text { Wearing } \\
\text { apparel }\end{array}$ & Wearing Apparel: Clothing, dressing and dyeing of fur \\
\hline 8 & $\begin{array}{l}\text { Leather } \\
\text { products }\end{array}$ & $\begin{array}{l}\text { Leather: tanning and dressing of leather; luggage, handbags, saddlery, } \\
\text { harness and footwear }\end{array}$ \\
\hline 9 & Wood products & $\begin{array}{l}\text { Lumber: wood and products of wood and cork, except furniture; articles } \\
\text { of straw and plaiting materials }\end{array}$ \\
\hline 10 & $\begin{array}{l}\text { Paper products, } \\
\text { publishing }\end{array}$ & $\begin{array}{l}\text { Paper \& Paper Products: includes publishing, printing and reproduction of } \\
\text { recorded media }\end{array}$ \\
\hline 11 & $\begin{array}{l}\text { Petroleum, coal } \\
\text { products }\end{array}$ & $\begin{array}{l}\text { Petroleum \& Coke: coke oven products, refined petroleum products, } \\
\text { processing of nuclear fuel }\end{array}$ \\
\hline 12 & $\begin{array}{l}\text { Chemical, } \\
\text { rubber, plastic } \\
\text { products }\end{array}$ & $\begin{array}{l}\text { Chemical Rubber Products: basic chemicals, other chemical products, } \\
\text { rubber and plastics products }\end{array}$ \\
\hline 13 & $\begin{array}{l}\text { Mineral } \\
\text { products n.e.c }\end{array}$ & Non-Metallic Minerals: cement, plaster, lime, gravel, concrete \\
\hline 14 & $\begin{array}{l}\text { Iron, Steel, \& } \\
\text { non-ferrous } \\
\text { metals }\end{array}$ & $\begin{array}{l}\text { Iron \& Steel: basic production and casting. Non-Ferrous Metals: } \\
\text { production and casting of copper, aluminum, zinc, lead, gold, and silver }\end{array}$ \\
\hline 15 & $\begin{array}{l}\text { Fabricated } \\
\text { metal products }\end{array}$ & $\begin{array}{l}\text { Fabricated Metal Products: Sheet metal products, but not machinery and } \\
\text { equipment }\end{array}$ \\
\hline 16 & $\begin{array}{l}\text { Motor vehicles } \\
\text { and parts }\end{array}$ & Motor Vehicles: cars, lorries, trailers and semi-trailers \\
\hline 17 & $\begin{array}{l}\text { Transport } \\
\text { equipment n.e.c }\end{array}$ & Other Transport Equipment: Manufacture of other transport equipment \\
\hline 18 & $\begin{array}{l}\text { Electronic } \\
\text { equipment }\end{array}$ & $\begin{array}{l}\text { Electronic Equipment: office, accounting and computing machinery, } \\
\text { radio, television and communication equipment and apparatus }\end{array}$ \\
\hline 19 & $\begin{array}{l}\text { Machinery and } \\
\text { equipment n.e.c }\end{array}$ & $\begin{array}{l}\text { Other Machinery \& Equipment: electrical machinery and apparatus n.e.c., } \\
\text { medical, precision and optical instruments, watches and clocks }\end{array}$ \\
\hline 20 & $\begin{array}{l}\text { Manufactures } \\
\text { n.e.c }\end{array}$ & Other Manufacturing: includes recycling \\
\hline 21 & $\begin{array}{l}\text { Electricity \& } \\
\text { Gas Production } \\
\text { and } \\
\text { Distribution }\end{array}$ & $\begin{array}{l}\text { Electricity: production, collection and distribution. Gas Distribution: } \\
\text { distribution of gaseous fuels through mains; steam and hot water supply }\end{array}$ \\
\hline
\end{tabular}




\begin{tabular}{lll}
\hline ID & Sector & Descriptions \\
\hline 22 & Water & Water: collection, purification and distribution \\
\hline 23 & Construction & Construction: building houses factories offices and roads \\
\hline 24 & Trade & $\begin{array}{l}\text { Trade: all retail sales; wholesale trade and commission trade; hotels and } \\
\text { restaurants; repairs of motor vehicles and personal and household goods; } \\
\text { retail sale of automotive fuel }\end{array}$ \\
& & $\begin{array}{l}\text { Other Transport: road, rail; pipelines, auxiliary transport activities; travel } \\
\text { agencies. Air transport }\end{array}$ \\
\hline 26 & Water transport & Water transport \\
\hline 27 & Communication & Communications: post and telecommunications \\
\hline 28 & $\begin{array}{l}\text { Financial } \\
\text { services n.e.c }\end{array}$ & $\begin{array}{l}\text { Other Financial Intermediation: includes auxiliary activities but not } \\
\text { insurance and pension funding (see next) }\end{array}$ \\
\hline 29 & Insurance & Insurance: includes pension funding, except compulsory social security \\
\hline 30 & $\begin{array}{l}\text { Other business } \\
\text { services }\end{array}$ & $\begin{array}{l}\text { Other Business Services: real estate, renting and business activities. } \\
\text { Dwellings: ownership of dwellings (imputed rents of houses occupied by } \\
\text { owners) }\end{array}$ \\
\hline 31 & $\begin{array}{l}\text { Recreational } \\
\text { and } \\
\text { services }\end{array}$ & $\begin{array}{l}\text { Recreation \& Other Services: recreational, cultural and sporting activities, } \\
\text { other service activities; private households with employed persons } \\
\text { (servants) }\end{array}$ \\
\hline 32 & $\begin{array}{l}\text { Public } \\
\text { administration } \\
\text { and defenc, } \\
\text { education, } \\
\text { health }\end{array}$ & $\begin{array}{l}\text { Other Services (Government): public administration and defense; } \\
\text { compulsory social security, education, health and social work, sewage and } \\
\text { refuse disposal, sanitation and similar activities, activities of membership } \\
\text { organizations n.e.c., extra-territorial organizations and bodies }\end{array}$ \\
\hline
\end{tabular}

Notes: n.e.c means not elsewhere classified

Source: Adapted from Bradri Narayanan and Walmsley (2008) 


\section{References}

BENSTON, G. J. \& KAUFMAN, G. G. 1996. The appropriate role of bank regulation. The Economic Journal, 688-697.

BOUMELLASSA, H., GOUEL, C. \& LABORDE, D. 2007. Bilateral and Sectoral Investment Relations at a World Scale Impact on Trade. Paris: Commission of the European Union - Directorate General for Trade.

BRADRI NARAYANAN, G. \& WALMSLEY, T. L. 2008. Global Trade, Assistance, and Production: The Gtap 7 Data Base. Center for Global Trade Analysis, Department of Agricultural Economics, Purdue University. .

DE WAAL, A., DUONG, H. \& TON, V. 2009. High performance in Vietnam: the case of the Vietnamese banking industry. Journal of Transnational Management, 14, 179-201.

DEE, P. 2005. A Compendium of Barriers to Services Trade. Canberra Crawford School of Economics and Government, Australian National University.

DEE, P. 2010. FTAP Model: Version 2_7a, Canberra, Crawford School of Public Policy.

DEE, P. \& DINH, H. 2008. The Sectoral Impact of Barriers to Trade in Insurance: A Cost- and Profit-based Approach. Canberra: Crawford School of Economics and Government, Australian National University.

DIHEL, N. \& SHEPHERD, B. 2007. Modal Estimates of Services Barriers. OECD Trade Policy Working Paper No. 51. OECD.

DINH, H. 2011. On Regulatory Barriers to Trade in Banking Services. PhD, Australian National University. Canberra.

DINH, H. 2012. Economy-wide impacts of liberalization in the Vietnamese banking sector. In: SAUVÉ, P., PASADILlA, G. \& MIKIC, M. (eds.) Service Sectors Reform: AsiaPacific Perspectives. ADB Institute and ArTNET.

DINH, H. 2013. Impact of Regulatory Barriers to Trade in Banking Services. In: DEE, P. (ed.) Priorities and Pathways in Services Trade Reform: Part 1 - Modeling and Quantitative Studies. World Scientific Studies in International Economics, World Scientific Publishing Co Pte Ltd.

GOWLAND, D. H. 1990. The regulation of financial markets in the 1990s, Edward Elgar.

HANOI NATIONAL ECONOMICS UNIVERSITY 2011. Research of informal employment in Vietnam: Current situation and solutions. Hanoi: Hanoi National Economics University.

HANSLOW, K., PHAMDUC, T. \& VERIKIOS, G. 2000. The structure of the FTAP model. Economic Analysis, 27, 30.

HOANG, V. Q. 2004. Fledgling Financial Markets in Vietnam's Transition Economy, 19862003, Brussels, Belgium, Université libre de Bruxelles.

IFC 2009. Enterprise Surveys Database. International Financial Corporation.

LEUNG, S. 2009. Banking and financial sector reforms in Vietnam. ASEAN Economic Bulletin, 26, 44-57.

LLEWELLYN, D. 1999. The economic rationale for financial regulation, Financial Services Authority London.

LLEWELLYN, D. T. 1986. The regulation and supervision of financial institutions, University of London. King's College, Institute of Bankers.

MCGUIRE, G. \& SCHUELE, M. 2000. Restrictiveness of international trade in banking services. In: FINDLAY, C. \& WARREN, T. (eds.) Impediments to trade in services: Measurement and policy implications. London and New York: Routledge.

VERIKIOS, G. \& ZHANG, X.-G. Sectoral impact of liberalising trade in services. The third Conference on Global Economic Analysis, 2000 Melbourne. 27-30.

VO, T. T., LE, X. S., DINH, H. M. \& TRINH, Q. L. 2004. The Vietnam Financial Market: Current Situations, Problems, and Policy Solutions Hanoi, Financial Publishing House. 
WARREN, T. \& FINDLAY, C. 2000. Measuring impediments to trade in services. GATS 2000: New Directions in Services Trade Liberalization, 57-84.

WORLD BANK 2014a. Vietnam - Financial sector assessment. Financial Sector Assessment Program (FSAP), Washington, DC, World Bank Group.

WORLD BANK 2014b. World development indicators 2014, Washington, DC, World Bank Group.

WORLD BANK undated. Questionnaires to Assess Services Trade Policy and Performance: Long Version. World Bank Research Program on Trade in Services. Washington DC: World Bank. 